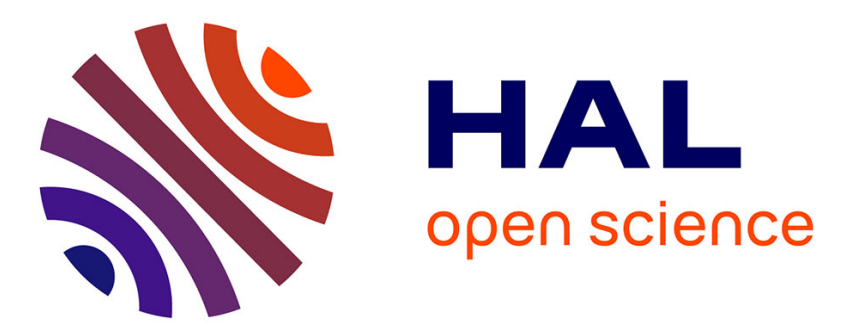

\title{
First evidence of the trisulfur radical ion S3- and other sulfur polymers in natural fluid inclusions
}

Guillaume Barré, Laurent Truche, Elena Bazarkina, Raymond Michels, Jean Dubessy

\section{- To cite this version:}

Guillaume Barré, Laurent Truche, Elena Bazarkina, Raymond Michels, Jean Dubessy. First evidence of the trisulfur radical ion S3- and other sulfur polymers in natural fluid inclusions. Chemical Geology, 2017, 462, pp.1-14. 10.1016/j.chemgeo.2017.03.027 . hal-02385099

\section{HAL Id: hal-02385099 \\ https://hal.science/hal-02385099}

Submitted on 28 Nov 2019

HAL is a multi-disciplinary open access archive for the deposit and dissemination of scientific research documents, whether they are published or not. The documents may come from teaching and research institutions in France or abroad, or from public or private research centers.
L'archive ouverte pluridisciplinaire HAL, est destinée au dépôt et à la diffusion de documents scientifiques de niveau recherche, publiés ou non, émanant des établissements d'enseignement et de recherche français ou étrangers, des laboratoires publics ou privés. 
3 Guillaume Barré ${ }^{1 *}$, Laurent Truche ${ }^{1,2}$, Elena F. Bazarkina ${ }^{1,3,4}$, Raymond Michels ${ }^{1}$, Jean

4 Dubessy ${ }^{1}$

$5{ }^{1}$ Université de Lorraine, CNRS, GeoRessources, UMR 7359, BP 70239, F-54506 Vandoeuvre-

6 lès-Nancy, France

$7 \quad{ }^{2}$ Université Grenoble Alpes, CNRS, ISTerre, UMR 5275, BP 53, 38041 Grenoble, France

$8{ }^{3}$ Institute of Geology of Ore Deposits, Mineralogy, Petrography and Geochemistry, Russian

9 Academy of Sciences, IGEM RAS, Staromonetny per. 35, 119017 Moscow, Russia

$10{ }^{4}$ Inst. Néel, UPR 2940 CNRS - Univ. Grenoble Alpes, F-38000 Grenoble, France

11 e-mail: guillaume.barre@univ-lorraine.fr

12 Abstract

13 Sulfur plays a key role in numerous processes occurring in the Earth's crust. However, its 14 speciation in deep and hot geological fluids remains poorly constrained. Here, we used 15 quantitative in-situ Raman spectroscopy on natural fluid inclusions from deep sedimentary 16 environments where thermochemical sulfate reduction (TSR) occurred to determine the sulfur

17 speciation at temperatures representative of their entrapment conditions $\left(100-300^{\circ} \mathrm{C}\right)$. Results 18 unambiguously demonstrate the presence of the trisulfur ion $\mathrm{S}_{3}{ }^{-}$and other polymeric $\mathrm{S}$ species $19\left(\mathrm{~S}_{\mathrm{n}}{ }^{2-} \pm \mathrm{S}_{\mathrm{n}}{ }^{0}\right)$ at temperature $(\mathrm{T})>100^{\circ} \mathrm{C}$, whereas only sulfide and sulfate were detected at $25^{\circ} \mathrm{C}$. 20 From 200 to $300^{\circ} \mathrm{C}$, sulfate and sulfide, the two dominant $\mathrm{S}$ species, contribute to $41 \pm 9 \%$ and $2159 \pm 9 \%$ of the mean total dissolved $\mathrm{S}$ concentration $\left(\left[\mathrm{S}_{\mathrm{tot}}\right]=0.25 \mathrm{~mol} / \mathrm{kg}_{\mathrm{H} 2 \mathrm{O}}=0.8 \mathrm{wt} \%\right)$ 22 respectively. The $\mathrm{S}_{3}$ concentration accounts for 0.2 to $3 \%$ of $\mathrm{S}_{\text {tot }}$ in this $\mathrm{T}$ range, with a 
23 maximum recorded concentration of $2.9 \times 10^{-2} \mathrm{~mol} / \mathrm{kg}_{\mathrm{H} 2 \mathrm{O}}(2780 \mathrm{ppm})$ at $300^{\circ} \mathrm{C}$. This observation

24 implies that the TSR process occurs under physico-chemical conditions that enhanced the

25 stability of $\mathrm{S}_{3}{ }^{-}$and other polymeric $\mathrm{S}$ species. This conclusion has important consequences for

26 the genesis of base metal sulfide deposits and sour gas fields where reduced sulfur originates

27 from TSR.

28 Keywords: $\mathrm{S}_{3}^{-}$; Fluid inclusion; Raman spectroscopy; Sulfur speciation; Thermochemical

29 Sulfate Reduction

30 1. Introduction

31 Sulfur speciation and concentration in deep basinal brines play a crucial role in the formation 32 of sour ( $\mathrm{H}_{2} \mathrm{~S}$-bearing) gas field (Orr, 1974; Worden and Smalley, 1996; Machel, 2001; Walters et

33 al., 2015; Cai et al., 2016) and the genesis of many sedimentary-hosted ore deposits (Heydari and

34 Moore, 1989; Basuki et al., 2008; Thom and Anderson, 2008). One of the most important

35 reactions controlling the sulfur behavior in deep sedimentary environments is the abiogenic

36 reduction of sulfate to sulfide coupled with the oxidation of hydrocarbons, which is termed

37 thermochemical sulfate reduction (TSR). This reaction occurs at temperature above $100-140^{\circ} \mathrm{C}$

38 and is under strong kinetic control (Kiyosu and Krouse, 1993; Goldhaber and Orr, 1995; Cross et

39 al., 2004; Thom and Anderson, 2008; Zhang et al., 2008; Truche et al., 2009; Yuan et al., 2013).

40 The sulfur speciation has also a major impact on the rate and extent of TSR, because both the

41 reactivity of dissolved sulfate compounds (e.g. $\mathrm{SO}_{4}{ }^{2-}, \mathrm{HSO}_{4}{ }^{-}, \mathrm{CaSO}_{4}{ }^{0}, \mathrm{MgSO}_{4}{ }^{0}$ ) and the relative

42 stability of intermediate valence sulfur species (e.g. thiosulfate, polysulfides, labile organic

43 sulfur compounds) drive the electron transfer from $\mathrm{S}^{+6}$ to $\mathrm{S}^{2-}$ (Goldstein and Aizenshtat, 1994;

44 Cai et al., 2003; Amrani et al., 2008; Ma et al., 2008; Gvirtzman et al., 2015). Most of our

45 knowledge of sulfur speciation in saline brines from deep burial diagenetic environments relies 
on measurements made on quenched fluids from surface springs, water/oil production wells, and

47 fluid inclusions entrapped in minerals. Sulfate and sulfide are the dominant dissolved sulfur

48 species in these environments, with concentrations up to $0.5 \mathrm{~mol} / \mathrm{kg}_{\mathrm{H} 2 \mathrm{O}}$ (Boiron et al., 1999;

49 Horita et al., 2002; Worden et al., 2003). Other intermediate valence sulfur species such as sulfite

$50\left(\mathrm{SO}_{3}{ }^{-}\right)$, thiosulfate $\left(\mathrm{S}_{2} \mathrm{O}_{3}{ }^{2-}\right)$, polythionates $\left(\mathrm{S}_{\mathrm{n}} \mathrm{O}_{6}{ }^{2-}\right)$, polysulfides $\left(\mathrm{S}_{\mathrm{n}}{ }^{2-}\right)$ or dissolved elemental

51 sulfur $\left(\mathrm{S}^{0}\right)$ have been found in surface hydrothermal springs, and sulfide rich water well

52 (Boulègue, 1978; Takano, 1987; Webster, 1987; Veldeman et al., 1991; Takano et al., 1994; Xu

53 et al., 1998; Kamyshny et al., 2008; Nordstrom et al., 2009; Kaasalainen and Stefánsson, 2011).

54 However, their speciation and concentration may not reflect the true sulfur chemistry in deep

55 geological fluids that is known to be very sensitive to temperature $(\mathrm{T})$, pressure $(\mathrm{P})$, redox, and

56 pH conditions (Giggenbach, 1974; Ohmoto and Lasaga, 1982; Barnes, 1997).

57 The recent discovery of the trisulfur ion $\mathrm{S}_{3}^{-}$in aqueous S-rich fluids from laboratory

58 experiments using in-situ Raman spectroscopy at $\mathrm{T}>200^{\circ} \mathrm{C}$, acidic-to-neutral pH (2-6), and

59 redox condition enabling coexistence of sulfate and sulfide has challenged our interpretation of

60 sulfur behavior in hydrothermal fluids (Pokrovski and Dubrovinsky, 2011; Chivers and Elder,

61 2013; Jacquemet et al., 2014; Truche et al., 2014; Pokrovski and Dubessy, 2015). Nevertheless,

62 little attention has been given to the sulfur speciation in natural geological fluids, and the

63 concentration of intermediate sulfur species at relevant T-P is unknown. To our knowledge there

64 is no study on sulfur speciation in natural fluid inclusions at elevated T.

65 Here, we performed quantitative in-situ analysis of sulfur speciation in well-preserved natural

66 fluid inclusions from a geological setting where TSR occurred. We used in-situ Raman

67 spectroscopy coupled to a heating stage to analyze samples under temperatures representative of

68 their entrapment conditions. 


\section{Geological setting}

70 For the purpose of this study, rock samples were selected from the Carnian evaporites (upper

71 Triassic), named "gypse nappe" formation, outcropping in the Arc Valley (French Alps),

72 between Modane and Sollières-l'Envers (Fig. 1). This geological formation exposes to the

73 surface a world-class evidence of TSR occurrence in previously deeply buried evaporites, with

74 coexistence of sulfate (anhydrite), sulfide (pyrite), and native sulfur at both macro (Fig. 2) and

75 microscopic scale (not shown). The Carnian evaporites belong to the Triassic formation marking

76 a major Alpine structural discontinuity between the Permian basement and the allochtonous

77 Piedmont unit of Cretaceous age (Fig. 1, see also Debelmas et al., 1989a; Strzerzynski et al.,

782012 and reference therein). They are characterized by massive anhydrite embedding dolomite

79 layers and smaller intercalations of micaschist. Elemental sulfur occurs as vugs within the

80 anhydrite or associated to the white well-crystallized dolomite as fracture infillings within the

81 brownish cryptocrystalline dolomite layers. Fluorite and quartz crystals ( $\mathrm{mm}$ to $\mathrm{cm}$ in size) are

82 also found disseminated within the anhydrite or the brownish cryptocrystalline dolomite (Fig.

83 2b). The Carnian formation is tectonically deformed. Anhydrite shows schistosity and folding

84 while dolomite shows boudinage levels from still recognizable layers to totally isolated blocs.

85 The formation has been affected by the Modane-Aussois metamorphic event that recorded an

86 isothermal exhumation during the Paleogene. The peak of metamorphism led to maximum

87 temperature and pressure around $350^{\circ} \mathrm{C}$ and $7.5 \mathrm{kbar}$ (Gabalda et al., 2009; Lanari et al., 2012;

88 Strzerzynski et al., 2012). The fluid inclusions studied here are preferentially located in the

89 anhydrite \pm quartz \pm fluorite veins that intersect the dolomitic "boudins", and are distributed in

90 plane, clusters or as isolated inclusions. They do not display any deformation. These textural 
91 features strongly suggest that the fluid inclusions were trapped during the retrograde

92 metamorphic pathway under brittle conditions, and not during the prograde pathway.

\section{3. Samples and methods}

\section{3.1. Choice of the host mineral}

95 The natural fluid inclusions studied here are hosted in quartz, fluorite or anhydrite. Quartz and

96 fluorite minerals are present as small crystals $(100 \mu \mathrm{m}$ to $1 \mathrm{~cm}$ of diameter) embedded in the

97 anhydrite matrix. Fluorite is the best host mineral to study sulfur speciation by Raman

98 spectroscopy, because of the absence of peaks overlap between fluorite and sulfur species.

99 However, thermal dilatation of fluorite may slightly change the liquid-vapor ratio in the fluid

100 inclusion (Bodnar and Bethke, 1984) and therefore change the sulfur speciation at elevated T.

101 Having in mind this limitation, and despite the fact that the evolution of sulfate and sulfide

102 concentration in quartz hosted fluid inclusions are identical within errors to those measured in

103 fluorite, we advise the reader that our quantitative concentration measurements of the various

104 sulfur species concentration in fluorite-hosted fluids inclusions at $\mathrm{T}$ above $200^{\circ} \mathrm{C}$ are given for

105 indicative purpose. Quartz has a lower thermal expansion than fluorite, but it has some Raman

106 peaks in the low wavenumber region that may hide the potential presence of polymeric sulfur

107 species. No fluid inclusions hosted in anhydrite were retained for sulfur speciation investigations,

108 owing to numerous peaks overlap between the host mineral and the dissolved sulfur species.

109 3.2. Fluid inclusions analysis

110 A total of 72 fluid inclusions from 3 different outcrops located in the Arc Valley (Fig. 1 and

111 Supplementary Table S1 and S2) were analyzed by microthermometry, Raman spectrometry, and

112 Fourier Transform Infrared spectrometry (FTIR, specific details in the Supplementary material).

113 The salinities and homogenization temperatures $\left(T_{\mathrm{h}}\right)$ of the fluid inclusions were obtained by 
114 microthermometry and Raman spectroscopy. Raman analyses were performed at $25-300^{\circ} \mathrm{C}$ using

115 a heating stage in order to study in-situ the composition of the trapped paleofluids. External

116 standard solutions of $\mathrm{HSO}_{4}^{-}, \mathrm{SO}_{4}{ }^{2-}$, and $\mathrm{H}_{2} \mathrm{~S}_{(\mathrm{aq})}$ were performed to establish Raman calibration

117 coefficients allowing quantitative analysis of each of these sulfur forms. Calibration coefficients

118 of $\mathrm{S}_{3}{ }^{-}$were derived from Pokrovski and Dubessy (2015). The complete analytical procedure is

119 described below.

120 3.2.1. Microthermometric analysis

121 Microthermometric measurements were performed on a Linkam THMSG600 heating-cooling

122 stage connected to an Olympus BX51 microscope allowing the analysis of fluid inclusions above

$1235 \mu \mathrm{m}$ in size. Homogenization temperatures and salinities were deduced from these

124 measurements. The stage was calibrated using natural and synthetic fluid inclusion standards

125 with the following phase transitions: the melting temperature of a $\mathrm{CO}_{2} \pm \mathrm{Ar}$ mixture at $-56.9^{\circ} \mathrm{C}$,

126 the ice melting and the critical homogenization temperatures of pure $\mathrm{H}_{2} \mathrm{O}$ at 0.0 and $374.0^{\circ} \mathrm{C}$,

127 respectively. According to the calibration curves, temperatures of phase changes have an

128 accuracy of about $\pm 0.1^{\circ} \mathrm{C}$ for ice melting and $\pm 1^{\circ} \mathrm{C}$ for total homogenization.

129 The composition of fluid inclusions in the $\mathrm{H}_{2} \mathrm{O}-\mathrm{NaCl}-\mathrm{CaCl}_{2}$ system was calculated using the

130 Microsoft Excel-based calculation sheet of Steele-MacInnis et al. (2011). We used the

131 combination of the measured temperatures of the final dissolution of halite and dissociation of

132 hydrates, hydrohalite $\left(\mathrm{NaCl} \cdot 2 \mathrm{H}_{2} \mathrm{O}\right)$ or antarcticite $\left(\mathrm{CaCl}_{2} \cdot 6 \mathrm{H}_{2} \mathrm{O}\right)$, as input parameters.

133 All studied fluid inclusions homogenize into the liquid phase. Total homogenization 134 temperatures $\left(\mathrm{T}_{h}\right)$ were measured in fluid inclusions hosted in quartz. Fluorite and anhydrite-

135 hosted fluid inclusions are not suitable for $T_{\mathrm{h}}$ measurements because of the deformation of the 136 crystal, and change of the internal volume of the inclusion upon heating (Bodnar and Bethke, 
137 1984; Vanko and Bach, 2005). However, their $T_{\mathrm{h}}$ are also given in Fig. 3 and Table S1 for 138 indicative purpose.

139 The fluid inclusions liquid-vapor ratio was estimated on two-dimensional sections by 140 measurements of the greatest area fraction for liquid and vapor phase for each fluid inclusion 141 using ImageJ (free software at http://rsb.info.nih.gov).

\section{3.2.2. Raman spectra acquisition}

143 Raman spectra were recorded at the GeoRessources laboratory (Nancy, France) with a 144 Labram HR spectrometer $\left({ }^{\circledR}\right.$ Jobin-Yvon, Horiba) coupled with a heating-stage dedicated to fluid 145 inclusion $\left({ }^{\circledR}\right.$ Linkam, THMS-600) or capillary $\left({ }^{\circledR}\right.$ Linkam, CAP 500) studies. Raman spectra were 146 mainly obtained using the $514 \mathrm{~nm}$ (green) $\mathrm{Ar}^{+}$laser excitation, with a laser power of $200 \mathrm{~mW}$ 147 implying a maximal laser power at the sample around $20 \mathrm{~mW}$. Some spectra were also recorded 148 at lower laser power ( 0.7 to $7 \mathrm{~mW}$ at the sample) using filters, and compared with the full power 149 spectra to ensure the absence of laser-induced phenomena such as sample overheating or 150 photochemical reaction. Some spectra were also obtained with the $488 \mathrm{~nm}$ (blue) line of the $\mathrm{Ar}^{+}$ 151 laser for a better identification of sulfur species exhibiting Raman resonance phenomena such as $152 \mathrm{~S}_{3}{ }^{-}, \mathrm{S}_{\mathrm{n}}{ }^{2-}$ or $\mathrm{S}_{\mathrm{n}}{ }^{0}$ ions (Steudel, 2003). As demonstrated by Pokrovski and Dubessy (2015), the use 153 of multiple excitation wavelengths allows more robust identification and quantification of sulfur

154 species that exhibit Raman resonance phenomena, such as $\mathrm{S}_{3}{ }^{-}$, because their Raman signal is 155 selectively enhanced at specific laser wavelengths, whereas that of non-resonant species such as 156 sulfate and sulfide is little affected.

157 The spectrometer was calibrated using the Raman stretching vibrations of a Si wafer (520.7 $158 \mathrm{~cm}^{-1}$ at $\left.20^{\circ} \mathrm{C}\right)$, and oxygen $\left(1555 \mathrm{~cm}^{-1}\right)$ and nitrogen $\left(2331 \mathrm{~cm}^{-1}\right)$ gas from the air. The acquisition 159 was performed using a grating of 1800 lines/mm, a slit width of $200 \mu \mathrm{m}$ and a confocal hole of $160500 \mu \mathrm{m}$ providing a spectral resolution of 0.5 to $1 \mathrm{~cm}^{-1}$. Spectral acquisition was collected with a 
161 time of 15 to $60 \mathrm{~s}$ per spectral window and 2 to 4 accumulations in the wavenumber interval 100 162 to $4200 \mathrm{~cm}^{-1}$. The use of an Olympus $100 \times$ objective coupled to the Raman spectrometer, 163 allowed the identification of the different phases (solid, liquid and vapor) present in the fluid 164 inclusions and to analyze them with a $1 \mu \mathrm{m}$ laser spot size on the sample. In addition, the focus 165 was tuned to optimize the intensity of the water O-H stretching band between 2800 and $3700 \mathrm{~cm}^{-}$

$166{ }^{1}$. The ratio of the area of a Raman band of an aqueous solute to the $\mathrm{OH}$ stretching band of water 167 is proportional to the solute concentration in the molarity scale at each temperature. Raman 168 spectra were processed using the LabSpec 5.64.15 software (®Jobin-Yvon, Horiba). This 169 software allows the baseline-subtraction and peak integration with a combination of Lorentzian 170 and Gaussian functions (pseudo-Voigt function) to determine precisely the frequency position 171 and the integrated peak area.

172 The samples were further heated step-by-step up to $300^{\circ} \mathrm{C}$ by steps of $50^{\circ} \mathrm{C}$. Each analysis 173 was performed after at least 15 minutes of down time at each step to allow the system to 174 equilibrate. The duration of Raman measurements carried out at $100^{\circ} \mathrm{C}$ and $300^{\circ} \mathrm{C}$ was increased 175 to 2 hours to ensure that a steady state was established. Salinities were also determined by 176 Raman spectroscopy according to the technique developed by Dubessy et al. (2002) and Caumon 177 et al. (2013), which is based on the deformation of the water stretching vibration band.

\section{3.3. Raman spectra calibration}

179 Sulfate $\left(\mathrm{SO}_{4}{ }^{2-}\right)$, hydrogen sulfate $\left(\mathrm{HSO}_{4}{ }^{-}\right)$, and hydrogen sulfide $\left(\mathrm{H}_{2} \mathrm{~S}_{(\mathrm{aq})}\right)$ concentration in 180 the liquid phase present in the fluid inclusions was derived using calibration equations 181 established from measurements in standard solutions (see Supplementary material for details on 182 the calibration procedure). Each standard solution was loaded in fused silica capillary capsule 183 (FSCC) purchased from Polymicro Technologies, LLC. This cell enables in-situ Raman 
184 measurements up to $\sim 500^{\circ} \mathrm{C}$ and $\sim 2$ kbar (Chou et al., 2008; Truche et al., 2014; Pokrovski and 185 Dubessy, 2015). It consists of round cross section silica-fused capillary tubing of $360 \mu \mathrm{m}$ 186 external and $100 \mu \mathrm{m}$ internal diameters. The capillary is sealed at both ends with a micro-torch 187 under vacuum and with frozen solution inside the capillary. The cell was heated step-by-step up 188 to $300^{\circ} \mathrm{C}$ on a heating-stage $\left({ }^{\circledR} \mathrm{CAP}-500\right.$ Linkam) which ensure a very good thermal stability $189\left( \pm 1^{\circ} \mathrm{C}\right)$ and negligible temperature gradients $\left(<1{ }^{\circ} \mathrm{C}\right.$ over the cell length of $\left.10-15 \mathrm{~mm}\right)$. To 190 increase the accuracy of concentration determination, the calibration solutions were measured 191 and processed identically to the fluid inclusions to establish calibration relationships allowing 192 quantitative analysis of $\mathrm{SO}_{4}{ }^{2-}, \mathrm{HSO}_{4}{ }^{-}$, and $\mathrm{H}_{2} \mathrm{~S}_{(\mathrm{aq})}$. In addition, the effect of salinity on the 193 calibration was evaluated at three different $\mathrm{NaCl}$ concentrations: 0,3 and 5 molar. To allow 194 quantitative comparisons of Raman peak areas in the liquid phase at different temperatures, the 195 spectra were normalized to the O-H stretching band of water between 2800 and $3700 \mathrm{~cm}^{-1}$. We 196 used the linear relationship between the concentration of each species $\left(\mathrm{C}_{\mathrm{i}}, \mathrm{mol} / \mathrm{L}\right)$ at given 197 temperature and its $\mathrm{H}_{2} \mathrm{O}$-normalized Raman peak area $\left(\mathrm{A}_{\mathrm{i}}\right)$ given by Pokrovski and Dubessy 198 (2015) to determine calibration coefficients of the major sulfur species:

$$
\mathrm{C}_{\mathrm{i}}=\mathrm{k}_{\mathrm{i}}(\mathrm{T}) \times \mathrm{A}_{\mathrm{i}}
$$

200 where $\mathrm{k}_{\mathrm{i}}$ is the calibration coefficient for sulfate, hydrogen sulfate and $\mathrm{H}_{2} \mathrm{~S}_{(\mathrm{aq})}$ at a given $\mathrm{T}$ (Fig. $2014 \mathrm{a}$ and Supplementary Table S6). Equation 2 was then applied to convert the corresponding 202 species concentration to molality units:

$$
\mathrm{m}_{\mathrm{i}}=\left(\mathrm{C}_{\mathrm{i}} / \rho_{\text {fluid }}\right) \times \mathrm{F}
$$

204 where $m_{i}$ is the molality of sulfate, hydrogen sulfate or $\mathrm{H}_{2} \mathrm{~S}_{(\mathrm{aq})}$ (in $\mathrm{mol} / \mathrm{kg}_{\mathrm{H} 2 \mathrm{O}}$ ), $\mathrm{C}_{\mathrm{i}}$, their 205 corresponding volumetric concentration (in $\mathrm{mol} / \mathrm{L}$ ), $\rho_{\text {fluid }}$ the density (in $\mathrm{g} / \mathrm{cm}^{3}$ ) of aqueous liquid 
206 at given $\mathrm{T}$ and $\mathrm{P}$, and $\mathrm{F}$, the molinity to molality conversion factor, $\mathrm{F}=1000 /(1000-\mathrm{W})$, where $\mathrm{W}$ 207 is the mass in grams of total dissolved solutes per $1 \mathrm{~kg}$ of liquid fluid.

208 As there is no standard for $\mathrm{S}_{3}^{-}$, the $\mathrm{kS}_{3}{ }^{-}$coefficient was calculated in the $200-300^{\circ} \mathrm{C}$ 209 temperature range assuming the same temperature dependence as for the corresponding $\mathrm{H}_{2} \mathrm{~S}$ 210 coefficient (see Supplementary material for details) according to: with $\mathrm{kS}_{3}{ }^{-}\left(500^{\circ} \mathrm{C}\right)=0.020 \pm 0.002 \mathrm{~mol} / \mathrm{L}$ and $\mathrm{k}_{\mathrm{H} 2 \mathrm{~S}}\left(500^{\circ} \mathrm{C}\right)=15.8 \pm 1 \mathrm{~mol} / \mathrm{L}$ calculated from

213 Pokrovski and Dubessy (2015) (Fig. 4b; Supplementary Table S7).

214 The empirical Raman calibrations established on standards measured in the silica capillary 215 are perfectly applicable to our natural fluid inclusions for the following reasons: i) there is no 216 significant difference in refraction index between quartz $(\mathrm{n}=1.544)$ and fused silica glass $(\mathrm{n}=$ 217 1.458), ii) the normalization of the Raman peaks area to the water stretching band avoids any 218 effect of sample geometry on the signal transmission, iii) the standards and the fluid inclusions 219 were processed identically (same configuration of the Raman spectrometer for signal 220 acquisition), iv) our standard solutions have salinity similar to that of the fluid inclusions, so the 221 effect of chlorinity on the shape/area of the water stretching band use to normalize the spectra is 222 accounted for.

223 The calibration coefficients reported here for sulfate, sulfide and $\mathrm{S}_{3}{ }^{-}$, combined with the 224 quantification limits for the Raman peak integrated area allow quantitative analysis down to $2250.02 ; 0.01$ and $0.0001 \mathrm{~mol} / \mathrm{kg}_{\mathrm{H} 2 \mathrm{O}}$ respectively. The detection limits for these species is about 10 226 times lower than the quantification limits. The overall uncertainties of the reported 227 concentrations for S-species in the fluid inclusions are between 5 and $30 \%$ of the value 228 depending on the calibration coefficient uncertainties and the signal-to-noise ratio, as estimated 
229 by fitting multiple spectra acquired at the same T-P at steady state, or using different baseline

230 choices and normalized peak areas.

\section{4. Results}

\section{4.1. Fluid inclusions characterization}

233 At $25^{\circ} \mathrm{C}$, all studied fluid inclusions contain several phases: aqueous liquid, gas, spherules of 234 native sulfur, and crystals of halite. All fluid inclusions display similar salinities (25 $\pm 4 \mathrm{wt} \%$ eq. $235 \mathrm{NaCl}$, with three times more $\mathrm{NaCl}$ than $\mathrm{CaCl}_{2}$ ) and fluid composition (Supplementary Table $\mathrm{S} 1$ 236 and $\mathrm{S} 2$ ). $T_{\mathrm{h}}$ values ranged from 98 to $355^{\circ} \mathrm{C}$, with a quasi-gaussian distribution centered at $237 \quad 176^{\circ} \mathrm{C}$ (Fig. 3).

238 Fluid inclusions composition at room temperature $\left(25 \pm 2^{\circ} \mathrm{C}\right)$ was analyzed by Raman 239 spectroscopy for each phase present: vapor, liquid and solids (Fig. 5). The vapor phase (Fig. 5a, 240 b) is dominated by $\mathrm{CO}_{2}$ and $\mathrm{H}_{2} \mathrm{~S}$ as shown by their intense $\mathrm{C}-\mathrm{O}$ and $\mathrm{S}-\mathrm{H}$ stretching vibrations 241 respectively at $1282-1386 \mathrm{~cm}^{-1}$ and $2603 \mathrm{~cm}^{-1}$. These two gases are the by-products of TSR 242 according to the general reaction:

$$
\mathrm{SO}_{4}{ }^{2-}+\mathrm{CH}_{4}+2 \mathrm{H}^{+}=\mathrm{H}_{2} \mathrm{~S}+\mathrm{CO}_{2}+2 \mathrm{H}_{2} \mathrm{O}
$$

Minor amount of $\mathrm{N}_{2}\left(v_{\mathrm{N}-\mathrm{N}}\right.$ at $\left.2330 \mathrm{~cm}^{-1}\right), \mathrm{CH}_{4}\left(\mathrm{v}_{\mathrm{C}-\mathrm{H}}\right.$ at $\left.2916 \mathrm{~cm}^{-1}\right)$ and $\mathrm{H}_{2}\left(\mathrm{v}_{\mathrm{H}-\mathrm{H}}\right.$ at $\left.4154 \mathrm{~cm}^{-1}\right)$

246 limited diffusion of $\mathrm{H}_{2}$ and no or very poor post-entrapment modifications. The diffusion of $\mathrm{H}_{2}$, 247 into and out of fluid inclusion has already been described at temperature above $450^{\circ} \mathrm{C}$ 248 (Mavrogenes and Bodnar, 1994), but such high temperature has never been reached in our 249 geological context. The presence of both $\mathrm{CH}_{4}$ and $\mathrm{H}_{2}$ indicates that the reducing conditions were 250 preserved. The N-N stretching vibration of $\mathrm{N}_{2}$ presents two peaks (at $2330 \mathrm{~cm}^{-1}$ and $2327 \mathrm{~cm}^{-1}$ ). 251 The first one is due the presence of air along the path of the laser between the sample and the 
252 microscope. The second one, more intense and slightly shifted to lower wavenumbers, is a clear

253 indication of the presence of $\mathrm{N}_{2}$ under pressure inside the fluid inclusion (Wang and Wright, 254 1973).

255 The aqueous liquid phase is characterized by the broad $\mathrm{O}-\mathrm{H}$ stretching band of water at $2562800-3700 \mathrm{~cm}^{-1} . \mathrm{SO}_{4}{ }^{2-}, \mathrm{H}_{2} \mathrm{~S}$ and $\mathrm{HS}^{-}$are ubiquitous dissolved sulfur species in the aqueous phase 257 of the fluid inclusions (Fig. 5c, d) as indicated by their most intense Raman peaks at $\sim 980 \mathrm{~cm}^{-1}$, $258 \sim 2590 \mathrm{~cm}^{-1}$ and $\sim 2570 \mathrm{~cm}^{-1}$, respectively. Hydrogen sulfate $\left(\mathrm{HSO}_{4}^{-}\right)$characterized by the $\mathrm{S}-\mathrm{O}$ 259 and S-OH stretching modes at $\sim 1050 \mathrm{~cm}^{-1}$ and $\sim 860 \mathrm{~cm}^{-1}$, respectively, is not observed in the 260 fluid inclusions at $25^{\circ} \mathrm{C}$. Dissolved $\mathrm{CO}_{2}$ and, to a lesser extent, $\mathrm{HCO}_{3}{ }^{-}$are also identified by their 261 C-O stretching vibrations at 1380 and $1015 \mathrm{~cm}^{-1}$, respectively. Another important feature 262 observed in the liquid phase is a small peak at $875 \mathrm{~cm}^{-1}$. This band belongs to the B-O stretching 263 vibrations of boric acid $\mathrm{B}(\mathrm{OH})_{3}$ (Servoss and Clark, 1957). Salinity values measured by Raman 264 spectroscopy $(25 \pm 2 \mathrm{wt} \%$ eq. $\mathrm{NaCl})$ are similar to those derived by microthermometry.

265 In addition, the fluid inclusions contain spherule of elemental sulfur clearly identified by the 266 characteristic features of the $\mathrm{S}_{8}$ ring molecules at $\sim 150$ (S-S bend), $\sim 219$ (S-S bend) and $\sim 470$ (S$267 \mathrm{~S}$ stretch) $\mathrm{cm}^{-1}$ (Fig. 5e, f). In some rare occasions, tiny crystals of celestine ( $\left.\mathrm{SrSO}_{4}\right)$, anhydrite $268\left(\mathrm{CaSO}_{4}\right)$ and calcite $\left(\mathrm{CaCO}_{3}\right)$ are also observed in fluid inclusions hosted in fluorite only. A 269 comparison with the RRUFF reference (RRUFF database, http://rruff.info/) is shown in Fig. 5e, $270 \mathrm{f}$, g. The presence of these weakly soluble sulfate minerals together with the high detection limit

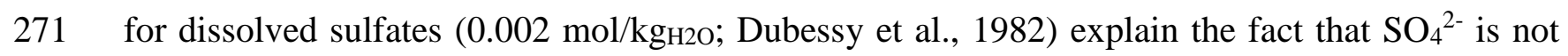
272 always detected in fluorite-hosted fluid inclusions.

273 Fourier Transform Infrared spectroscopy (FTIR) was also performed on some fluid 274 inclusions in order to identify potential organic compounds. The typical vibrations of a $\mathrm{CH}_{2}$ 
275 functional group at 2849 and $2920 \mathrm{~cm}^{-1}$ are clearly visible on the spectra displayed in

276 Supplementary Fig. S1. They may indicate the presence of a dissolved organic compound, but

277 the absence of other characteristic vibrations prevents a better identification.

\section{4.2. Sulfur speciation at elevated temperatures}

279 Below $100^{\circ} \mathrm{C}$, the Raman spectra show no changes with heating, even after 2 hours of 280 continuous heating. At $100^{\circ} \mathrm{C}$, native sulfur spherules begin to dissolve according to its 281 disproportionation reaction under hydrothermal conditions yielding mainly sulfate and sulfide:

282

283

284 heating up to $300^{\circ} \mathrm{C}$ in the liquid phase of fluid inclusions (Fig. 6). This main peak is associated 285 with resonant higher-order overtones $2 v, 3 v$ and $4 v$ at $1068,1608,2133 \mathrm{~cm}^{-1}$. These 286 characteristic features correspond without ambiguity to the resonance spectrum of the trisulfur $287 \mathrm{~S}_{3}{ }^{-}$ion induced by the enhanced symmetric S-S stretching vibration (Pokrovski and 288 Dubrovinsky, 2011). The trisulfur ion $\mathrm{S}_{3}{ }^{-}$is unambiguously identified by the main $\mathrm{S}-\mathrm{S}$ 289 symmetric bending ( $\delta$ ) vibration at $\sim 240 \mathrm{~cm}^{-1}$ and stretching (v) vibration at $\sim 532 \mathrm{~cm}^{-1}$, in 290 agreement with previous work (Pokrovski and Dubrovinsky, 2011; Chivers and Elder, 2013; 291 Pokrovski and Dubessy, 2015). Because $\mathrm{S}_{3}{ }^{-}$absorbs at $\sim 600 \mathrm{~nm}$, it exhibits a resonance Raman 292 phenomenon with laser frequencies close to its absorption wavelength (Ar+, $514 \mathrm{~nm}$ ). The 293 characteristic progression of the overtones $\delta+v, 2 v, 3 v, 4 v, 5 v$ and even $6 v(\sim 780,1070,1600$, 2942130,2665 and $3198 \mathrm{~cm}^{-1}$, respectively), is clearly visible in all Raman spectra recorded at T $295 \geq 100^{\circ} \mathrm{C}$ (Fig. 6).

296 Another important Raman feature clearly visible in the liquid phase is a broad peak at $407 \mathrm{~cm}^{-}$

$297{ }^{1}$ with a shoulder at $440 \mathrm{~cm}^{-1}$, accompanied by another poorly resolved band at $800-850 \mathrm{~cm}^{-1}$ 
298 (Fig. 6a, c), which increases in intensity from 150 to $300^{\circ} \mathrm{C}$. These Raman bands belong to S-S 299 stretching vibrations (Steudel, 2003). All these features are better visible with the blue laser (488

$300 \mathrm{~nm})$ because of the much lower overlapping with the $v_{1}\left(\mathrm{~S}_{3}{ }^{-}\right)$band compared to green-laser 301 spectra and enhanced Raman signal at this laser wavelength (Supplementary Fig. S2). These 302 Raman features strongly suggest the presence of polysulfide ions $\left(v_{\mathrm{s}}, \mathrm{cm}^{-1}: \mathrm{S}_{2}^{-} \sim 590, \mathrm{~S}_{2}{ }^{2-} \sim 451\right.$, $303 \mathrm{~S}_{3}{ }^{2-} \sim 476, \mathrm{~S}_{4}^{-} \sim 384$ and $439, \mathrm{~S}_{4}{ }^{2-} \sim 482, \mathrm{~S}_{5}{ }^{2-} \sim 432, \mathrm{~S}_{6}{ }^{2-} \sim 373$ and 453; Chivers and Lau, 1982). 304 Polysulfide ions $\left(\mathrm{S}_{\mathrm{n}}{ }^{2-}\right)$ are known to promote $\mathrm{S}_{3}^{-}$formation through their 305 dissociation/disproportionation (Chivers and Elder, 2013). Zero-valent sulfur polymeric 306 molecules, $\mathrm{S}_{\mathrm{n}}{ }^{0}$, other than $\mathrm{S}_{8}{ }^{0}$ (aq) may also display similar Raman characteristics $\left(v_{\mathrm{s}}, \mathrm{cm}^{-1}: \mathrm{S}_{2}{ }^{0}\right.$ $307 \sim 717, \mathrm{~S}_{3}{ }^{0} \sim 583, \mathrm{~S}_{4}{ }^{0} \sim 352$ and 674; Chivers and Lau, 1982). $\mathrm{S}_{\mathrm{n}}{ }^{0}$ species were also detected by 308 Pokrovski and Dubessy (2015) in $\mathrm{K}_{2} \mathrm{~S}_{2} \mathrm{O}_{3} \pm \mathrm{HCl}$ solutions at $\mathrm{T}$ above $200^{\circ} \mathrm{C}$. However, we 309 believe that $\mathrm{S}_{4}{ }^{2-}$ or $\mathrm{S}_{6}{ }^{2-}$ ions are the major species accounting for the $400-440 \mathrm{~cm}^{-1}$ Raman bands 310 because these polysulfides absorb light at $440-450 \mathrm{~nm}$ and therefore have a pronounced Raman 311 resonance of their S-S stretching bands with $488 \mathrm{~nm}$ laser excitation (Chivers and Lau, 1982).

312 The characteristic H-S Raman vibrations at $2400-2600 \mathrm{~cm}^{-1}$ of $\mathrm{HS}_{\mathrm{n}}{ }^{-}$or $\mathrm{H}_{2} \mathrm{~S}_{\mathrm{n}}{ }^{0}$ species (Dubessy et 313 al., 2008) are not detected in our fluid inclusions. The existence of $\mathrm{HS}_{\mathrm{n}}^{-}$ions in our fluid 314 inclusions at elevated temperatures cannot be excluded; however we have neither clear 315 spectroscopic evidence nor any thermodynamic data to support their presence. Indeed, the 316 stability constants of $\mathrm{HS}_{\mathrm{n}}{ }^{-}$ions are available only at $25^{\circ} \mathrm{C}$ (Boulègue and Michard, 1978; Millero, 317 1986; Williamson and Rimstidt, 1992). At $25^{\circ} \mathrm{C}$, the maximum concentration of $\mathrm{HS}_{\mathrm{n}}{ }^{-}$ions is 318 reached at $\mathrm{pH} \sim 7$, but it remains 3 orders of magnitudes lower than that of $\mathrm{S}_{\mathrm{n}}^{2-}$ ions. Polysulfides 319 concentrations decrease under acidic conditions. 
320 Heating-cooling cycles were performed in order to ensure that the formation of $\mathrm{S}_{3}{ }^{-}$and 321 polymeric S species was reversible (Supplementary Fig. S3). A fluid inclusion was first heated to

$322300^{\circ} \mathrm{C}$, cooled down to $100^{\circ} \mathrm{C}$ and heated again to $300^{\circ} \mathrm{C}$. The appearance and disappearance of

$323 \mathrm{~S}_{3}{ }^{-}$and $\mathrm{S}_{\mathrm{n}}{ }^{2-}\left( \pm \mathrm{S}_{\mathrm{n}}{ }^{0}\right)$ species are clearly visible along this temperature path. On re-heating the fluid

324 inclusion to $300^{\circ} \mathrm{C}$ (i.e. after cooling), one can observe that the Raman peak area ratio of these

325 species is exactly the same than the one recorded previously at the same temperature

326 (Supplementary Fig. S3). Because the aqueous sulfur speciation is dominated by sulfate and

327 sulfide in our fluid inclusions (see below), the reversible formation of $\mathrm{S}_{3}{ }^{-}$and $\mathrm{S}_{\mathrm{n}}{ }^{2-}\left( \pm \mathrm{S}_{\mathrm{n}}{ }^{0}\right)$ does not

328 affect significantly the concentration of sulfate and sulfide. In addition, the Raman spectra

329 acquired at $\mathrm{T}$ up to $300^{\circ} \mathrm{C}$ show no changes over 2 hours at a constant temperature. The rapid

330 (few tens of minutes) establishment of a steady state concentration of $\mathrm{S}_{3}{ }^{-}$and polymeric $\mathrm{S}$

331 species, and their reversible formation indicate that chemical equilibrium is likely to be attained

332 for these intermediate valence sulfur species.

\section{4.3. Sulfur species concentration in fluid inclusions}

334 The calibration coefficients established above enable estimation of $\mathrm{SO}_{4}{ }^{2-}, \mathrm{H}_{2} \mathrm{~S}$ and $\mathrm{S}_{3}{ }^{-}$ 335 concentration from normalized integrated area of their Raman bands in the fluid inclusions (Eq.

336 1). These concentrations are then converted in molality using Equation 2. The fluid density 337 needed to convert molarity to molality is estimated to be about $1.19 \mathrm{~g} / \mathrm{cm}^{3}$ at $25^{\circ} \mathrm{C}$. This 338 estimation is based on the salinities of the fluid inclusion with the assumption that $\mathrm{NaCl}$ is the 339 principal constituent in the system (Haas, 1976; Pitzer et al., 1984). Fluid density evolution with 340 T was further calculated using the model provided by Mao and Duan (2008).

341 The mean total dissolved sulfur concentration ( $\left.\mathrm{S}_{\mathrm{tot}}\right)$ is $0.14 \pm 0.03 \mathrm{~mol} / \mathrm{kg}_{\mathrm{H} 2 \mathrm{O}}$ (i.e. $0.45 \mathrm{wt} \%$ ) at $34225^{\circ} \mathrm{C}$, with sulfate and sulfide contributing to $67 \pm 2 \%$ and $33 \pm 2 \%$ of $\mathrm{S}_{\text {tot }}$, respectively in all 
343 inclusions. Upon heating above $100^{\circ} \mathrm{C}$, both sulfate and sulfide concentrations increase due to

344 elemental sulfur disproportionation. From 200 to $300^{\circ} \mathrm{C}, \mathrm{S}_{\text {tot }}$ concentration remain constant 345 around $0.25 \pm 0.13 \mathrm{~mol} / \mathrm{kg}_{\mathrm{H} 2 \mathrm{O}}(\sim 0.8 \mathrm{wt} \%)$, with sulfate and sulfide being the predominant

346 dissolved sulfur species, and contributing to $41 \pm 9 \%$ and $59 \pm 9 \%$ of $\mathrm{S}_{\text {tot }}$ respectively. This

347 change in the sulfate/sulfide ratio from $25^{\circ} \mathrm{C}$ to $200^{\circ} \mathrm{C}$ is in line with elemental sulfur 348 disproportionation, which produces 3 times more sulfide than sulfate (Equation 5). The 349 temperature behavior of sulfate and sulfide is identical within errors in all studied fluid 350 inclusions. The established calibration coefficients for $\mathrm{S}_{3}^{-}$allow the calculation of its 351 concentrations from 200 to $300^{\circ} \mathrm{C}$ and reasonable extrapolation down to $150^{\circ} \mathrm{C}$. $\mathrm{S}_{3}{ }^{-}$accounts for 3520.2 to $3 \%$ of $S_{\text {tot }}$ in this $\mathrm{T}$ range with corresponding mean concentrations increasing from $(4.7 \pm$ $3532.1) \times 10^{-4}$ to $(7.3 \pm 5.6) \times 10^{-3} \mathrm{~mol} / \mathrm{kg}_{\mathrm{H} 2 \mathrm{O}}$ (Fig. 7, Table 1). The maximum measured 354 concentration of $\mathrm{S}_{3}{ }^{-}$is $2.9 \times 10^{-2} \mathrm{~mol} / \mathrm{kg}_{\mathrm{H} 2 \mathrm{O}}(2780 \mathrm{ppm})$ at $300^{\circ} \mathrm{C}$.

355 Polymeric $\mathrm{S}$ species, other than $\mathrm{S}_{3}^{-}$, are more difficult to quantify because of the absence of 356 standards and important discrepancies associated to mass balance calculations, but a rough 357 estimation can be deduced using some assumptions on the calibration coefficients values. We 358 apply either the calibration coefficient of a resonant species $\left(\mathrm{k}_{\mathrm{S} 3-}\right)$ or the mean value of the non359 resonant sulfur species (estimated by extrapolation of the $\mathrm{k}_{\mathrm{H} 2 \mathrm{~S}}$ and the $\mathrm{ksO}_{\mathrm{S}}$ ) to the normalized 360 area of the main peaks of $\mathrm{S}_{\mathrm{n}}{ }^{2-}\left( \pm \mathrm{S}_{\mathrm{n}}{ }^{0}\right)$ species at $407 \mathrm{~cm}^{-1}$, according to Equation 1. These two 361 calibration coefficients (Supplementary Fig. S5) provide two extreme boundaries for the $\mathrm{S}_{\mathrm{n}}{ }^{2-}$ $362\left( \pm \mathrm{S}_{\mathrm{n}}{ }^{0}\right)$ concentration: the upper one is given by the non-resonant calibration coefficients and the 363 lower one is given by $\mathrm{S}_{3}{ }^{-}$calibration coefficients. This approach provides a wide range of $\mathrm{S}_{\mathrm{n}}{ }^{2-}$ $364\left( \pm \mathrm{S}_{\mathrm{n}}{ }^{0}\right)$ species concentrations covering two orders of magnitude from $2.2 \times 10^{-3}$ to $1.2 \times 10^{-1}$ 
$365 \mathrm{~mol} / \mathrm{kg}_{\mathrm{H} 2 \mathrm{O}}$ at $300^{\circ} \mathrm{C}$ (Fig. 7). Despite important uncertainty, it is noteworthy that the

366 concentration of the polymeric species is far from being negligible.

\section{5. Discussion}

\section{5.1. Representativeness and preservation of the fluid inclusions}

369 Here, all the studied fluid inclusions display the same textural and chemical features

370 irrespective of their host minerals: i) same irregular shape, ii) same liquid-vapor ratio $(\approx 8 \% \pm$ $3714 \%$ ) and chemistry, iii) same salinities, and iv) same sulfur speciation. The fluid inclusions

372 contain $\mathrm{H}_{2}$ and $\mathrm{CH}_{4}$, demonstrating that the reducing conditions have been preserved. This 373 observation does not contradict with the presence of sulfate in the geological fluid because its 374 reduction is under strong kinetic control, and because it is constantly supplied by sulfate minerals 375 dissolution, most notably anhydrite. These characteristics together with the absence of secondary 376 inclusion halo provide strong evidences for very limited post-entrapment modifications (Bodnar, 377 2003). The relatively large range of $T_{\mathrm{h}}$ contrasts with the narrow range of measured salinities. It 378 may indicate different entrapment temperature of a single fluid type during the retrograde 379 metamorphism phase with the lowest $\mathrm{T}$ as the limit of fluid entrapment and the highest one the 380 peak of metamorphism conditions around $350^{\circ} \mathrm{C}$ (Strzersynski et al., 2012). We therefore assume 381 that we analyzed the fluid composition trapped during the exhumation of the evaporites in a 382 closed system (no fluid mixing, and degassing). $\mathrm{H}_{2} \mathrm{~S}$ migration from deeper reservoirs is highly 383 improbable in the present case, because the fluid inclusions located in the white quartzite from 384 the lower Trias, which is stratigraphically below the carnian evaporites (Strzerzynski et al., 385 2012), are free of $\mathrm{H}_{2} \mathrm{~S}$ (Supplementary Table S2).

386 Sulfur speciation investigated here at $\mathrm{T}$ above $100^{\circ} \mathrm{C}$ after few hours of equilibration time is 387 probably far from sulfate-sulfide equilibrium for the two following reasons: i) the reducing 
conditions imposed by the presence of both $\mathrm{H}_{2}$ and $\mathrm{CH}_{4}$ in the fluid inclusions imply that $\mathrm{H}_{2} \mathrm{~S}$ is

389 the thermodynamically predicted stable sulfur redox end member, and that the TSR process was

390 not completed, and ii) more than 10 years are required to attain $90 \%$ of equilibrium between

391 sulfate and sulfide in aqueous solution at $200^{\circ} \mathrm{C}$, neutral $\mathrm{pH}$ condition and $\Sigma \mathrm{S}=0.1 \mathrm{~mole} / \mathrm{kg}_{\mathrm{H} 2 \mathrm{O}}$

392 (Ohmoto and Lasaga, 1982). By contrast, a local equilibrium between $\mathrm{S}_{-} \mathrm{S}_{\mathrm{n}}{ }^{0}-\mathrm{S}_{3}{ }^{-}$and the dominant

393 sulfate and sulfide forms may be achieved rapidly (within minutes) as demonstrated here by the

394 reversible formation (Supplementary Fig. S3) and the steady state concentration of these sulfur

395 species at $\mathrm{T}>200^{\circ} \mathrm{C}$ in our fluid inclusion. In addition, it has been experimentally demonstrated

396 that $\mathrm{S}_{3}{ }^{-}$is formed upon heating sulfate-sulfide mixtures at $\mathrm{T} \geq 100^{\circ} \mathrm{C}$ within few tens of minutes

397 (Truche et al., 2014), without any elemental sulfur or thiosulfate in the system initially. The same

398 conclusion has been reached by Pokrovski and Dubessy $(2015)$ at $\mathrm{T} \geq 300^{\circ} \mathrm{C}$. In this study, $\mathrm{S}_{3}{ }^{-}$

399 has been also observed in some natural fluid inclusions containing only sulfates and sulfides at

400 room temperature and no elemental sulfur (Supplementary Table S1). These independent

401 observations imply that the initial disproportionation of elemental sulfur or thiosulfate is not

402 mandatory for $\mathrm{S}_{3}{ }^{-}$and polysulfides to appear and, more importantly, that sulfate cannot be

403 considered as a non-reactive species at the time scale of these experiments, even at temperatures

404 as low as $100^{\circ} \mathrm{C}$. Thus, these stable intermediate valence sulfur species will form and remain in

405 solution as long as sulfate and sulfide coexist, and their concentrations can be predicted by 406 thermodynamic modeling (see section 5.2. below).

\section{5.2. Thermodynamic calculations}

408 Equilibrium concentrations of sulfur species in the fluid phase were modeled using the 409 Phreeqc software (Parkhurst and Appelo, 1999) and an updated version of the llnl database 410 (Johnson et al., 1992). The stability constants for $\mathrm{S}_{3}{ }^{-}, \mathrm{S}_{8}{ }^{0}$ and $\mathrm{S}_{\mathrm{n}}{ }^{2-}$ were updated using the HKF 
411 equation of state and HKF parameters estimated for these species (Johnson et al., 1992;

412 Kamyshny et al., 2007; Pokrovski and Dubessy, 2015 and updated databases at

413 http://geopig.asu.edu/?q=tools; specific details in the Supplementary materials). In the first round

414 of modeling (Fig. 8a), sulfate-sulfide concentrations correspond to our Raman measurements at

415 room temperature $\left(0.09 \mathrm{~mol} / \mathrm{kg}_{\mathrm{H} 2 \mathrm{O}}\right.$ and $0.05 \mathrm{~mol} / \mathrm{kg}_{\mathrm{H} 2 \mathrm{O}}$, respectively), and the initial amount of

416 elemental sulfur in the system $(0.11$ mole $S)$ is proportional to the one calculated in the fluid

417 inclusions based on geometrical considerations. The redox potential is imposed by the sulfate-

418 sulfide coexistence. The fluid acidity is buffered by fluid equilibrium with calcite and 10 bars of

$419 P\left(\mathrm{CO}_{2}\right)$ that imposed a $\mathrm{pH}$ around 5 at $\mathrm{T}>100^{\circ} \mathrm{C}$. Such a $\mathrm{pH}$ value is in agreement with the

420 speciation of sulfate (only $\left.\mathrm{SO}_{4}{ }^{2-}\right)$, sulfide $\left(\mathrm{H}_{2} \mathrm{~S}\right.$ and minor $\left.\mathrm{HS}^{-}\right)$and carbonate $\left(\mathrm{CO}_{2}\right.$ and minor

$421 \mathrm{HCO}_{3}{ }^{-}$) observed in the fluid inclusions at elevated $\mathrm{T}$ (Supplementary Fig. S8). We advise the

422 reader that this $\mathrm{pH}$ value is close to neutrality at $\mathrm{T}>100^{\circ} \mathrm{C}$, because of the strong decrease of the

423 dissociation constant of water (the neutrality decrease from $\mathrm{pH}=6$ to $\mathrm{pH}=5.5$ with temperature

424 increasing from 100 to $250^{\circ} \mathrm{C}$ ). This range of $\mathrm{pH}$ is compatible with the very low $\mathrm{HSO}_{4}^{-}$

425 concentration observed in natural sedimentary formation waters (a typical range of $\mathrm{pH}$ is

426 between 6.5 and 8.5 at $25^{\circ} \mathrm{C}$; Collins, 1975). The salinity is fixed at $3.3 \mathrm{~mol} / \mathrm{kg}_{\mathrm{H} 2 \mathrm{O} \mathrm{NaCl}}$ and 1.6

$427 \mathrm{~mol} / \mathrm{kg}_{\mathrm{H} 2 \mathrm{O}} \mathrm{CaCl}_{2}$ to mimic the salinity of our fluid inclusions. The extended Debye-Huckel

428 equation for activity coefficients of $\mathrm{NaCl}$ - and $\mathrm{CaCl}_{2}$-dominated electrolytes can be applied to

429 such high ionic strengths with reasonable accuracy in the range of temperature explored in this

430 study (Helgeson et al., 1981). Simulations performed at lower ionic strength (i.e. $1 \mathrm{~mol}^{\mathrm{k}} \mathrm{kg}_{\mathrm{H} 2 \mathrm{O}}$ )

431 provide very similar results. Over the entire $\mathrm{T}$ range $\left(25-300^{\circ} \mathrm{C}\right)$ the dominant species are

432 sulfates and sulfides. At $\mathrm{T}>100^{\circ} \mathrm{C}, \mathrm{S}_{3}{ }^{-}$is the third most abundant sulfur species predicted in the

433 system with concentrations rising up to $1.37 \times 10^{-3} \mathrm{~mol} / \mathrm{kg}_{\mathrm{H} 2 \mathrm{O}}$ at $200-300^{\circ} \mathrm{C}$. These 
434 thermodynamic predictions are in perfect agreement with our quantitative measurements using 435 in-situ Raman spectroscopy (Table 1 and S10). Concerning other polymeric sulfur species, our 436 preliminary Raman estimations, based on Raman calibration coefficients assumption, give $\mathrm{S}_{\mathrm{n}}{ }^{2-}$ $437\left( \pm \mathrm{S}_{\mathrm{n}}{ }^{0}\right)$ concentrations $\left(10^{-3}-10^{-2} \mathrm{~m}\right.$, Fig. 7) far above those predicted thermodynamically $\left(10^{-5}-\right.$ $43810^{-4}$ m, Fig. 8) and much higher than that of $\mathrm{S}_{8(\mathrm{aq})}$. Such conclusions imply that $\mathrm{S}_{\mathrm{n}}{ }^{2-}$ and $\mathrm{S}_{\mathrm{n}}{ }^{0}$ 439 species must not be ignored in natural fluids and that further studies are needed to determine 440 properly their thermodynamic stability at high T-P.

441 In a second round of modeling (Fig. 8b, c, d), $\mathrm{S}_{\text {tot }}$ was fixed at a given value without any 442 specification on the sulfate-sulfide concentrations (elemental sulfur solubility providing the 443 upper limit for $S_{\text {tot }}$ concentration in Fig. 8b). The sulfur speciation was then modeled as a 444 function of three different physical-chemical parameters $\left(\mathrm{S}_{\mathrm{tot}}, f\left(\mathrm{O}_{2}\right)\right.$ and $\left.\mathrm{pH}\right)$. The choice of $\mathrm{f}\left(\mathrm{O}_{2}\right)$ 445 value buffered by Hematite-Magnetite (HM) equilibrium is in line with expectation from typical 446 hydrocarbon reservoirs in nature (Seewald, 2001; Richard et al., 2005). Note that Hematite447 Magnetite-Pyrite assemblage, also relevant in the context of deep sedimentary settings gives the 448 same $f\left(\mathrm{O}_{2}\right)$ as the HM assemblage, but also control the $f\left(\mathrm{H}_{2} \mathrm{~S}\right)$. In our case, the $f\left(\mathrm{H}_{2} \mathrm{~S}\right)$ is not 449 buffered, because iron is clearly limiting.

450 Whatever the chosen conditions in the sedimentary studied domain, sulfate and sulfide are 451 always the dominant $\mathrm{S}$ species. However, $\mathrm{S}_{3}^{-}$may represent a significant contribution to the 452 sulfur budget if the following conditions are satisfied: 1) total sulfur concentration above $0.1 \mathrm{~m}$, 453 2) $\left.\mathrm{T}>150^{\circ} \mathrm{C}, 3\right)$ redox potential or $f\left(\mathrm{O}_{2}\right)$ enabling sulfate-sulfide coexistence, i.e. close to the 454 hematite-magnetite buffer, and 4) slightly acidic to neutral $\mathrm{pH}$. Such a conclusion has also been 455 reached for temperatures higher than $200^{\circ} \mathrm{C}$ by Pokrovski and Dubessy (2015). Figure $8 \mathrm{c}$ and $\mathrm{d}$ 456 show that when concentration of sulfates is much higher than that of sulfides, $\mathrm{S}_{3}{ }^{-}$and other 
457 intermediate valence sulfur species have concentrations lower than $10^{-6} \mathrm{~mol} / \mathrm{kg}_{\mathrm{H} 2 \mathrm{O}}$. The same 458 scenario is observed, albeit less pronounced, when sulfides concentration is much higher than 459 that of sulfates. However, in this latter case, $\mathrm{S}_{3}{ }^{-}$concentration is one or two order of magnitude 460 higher than those of the other intermediate valence sulfur species.

461 Note that $\mathrm{S}_{\mathrm{n}}{ }^{2-}$ and $\mathrm{S}_{\mathrm{n}}{ }^{0}$ species probably contribute to the sulfur budget in a similar, or even

462 more important, proportion as $\mathrm{S}_{3}{ }^{-}$in the range $100-300^{\circ} \mathrm{C}$, but their thermodynamic properties 463 are currently poorly constrained at elevated $\mathrm{T}$ or unknown and require further studies.

\section{5.3. Geochemical implications}

465 The characteristic blue color of the $\mathrm{S}_{3}{ }^{-}$chromophore ion and its UV-visible and Raman 466 spectral patterns in aqueous solutions has already been noticed in numerous experimental studies 467 involving sulfate and sulfide mixtures at $\mathrm{T}$ above $100^{\circ} \mathrm{C}$ (Giggenbach, 1968; Uyama et al., 1985; 468 Pokrovski and Dubrovinsky, 2011; Jacquemet et al., 2014). However, the discovery of both $\mathrm{S}_{3}{ }^{-}$

469 and other polymeric $\mathrm{S}$ species at the millimolar concentration level at $\mathrm{T}$ as low as $100^{\circ} \mathrm{C}$ in 470 natural fluid inclusions associated with a sedimentary formation where TSR occurred is a new 471 finding. These new data from natural samples corroborate the experimental discovery that $\mathrm{S}_{3}{ }^{-}$is a 472 major stable intermediate valence $S$ species involved in the reaction path of abiogenic sulfate 473 reduction (Truche et al., 2014), and support the fact that disproportionation reaction of sulfur is a 474 key step for TSR (Yuan et al., 2013). The onset temperature of TSR in nature around $100-140^{\circ} \mathrm{C}$ 475 corresponds remarkably well to the rise of $S_{3}{ }^{-}$and $S_{n}{ }^{0}$ concentrations (Fig. 7 and Fig. 8a). 476 Therefore, $S_{3}{ }^{-}$is an important reactive species in the TSR process for the following reasons: i) 477 the radical nature makes it very reactive, ii) the high concentration compared to the other 478 potential intermediate valence sulfur species taking part in the TSR process increases the contact 479 probability with the reducing agent, and iii) the TSR process itself results from an interaction 
480 between $\mathrm{S}_{3}{ }^{-}$and the electron donor that shift the equilibrium between sulfate and sulfide (Truche 481 et al., 2014).

482 This study opens up new perspectives on TSR isotopic record (Watanabe et al., 2009; Oduro 483 et al., 2011; Gvirtzman et al., 2015; Cai et al., 2016; Meshoulam et al., 2016). Indeed, there are 484 numerous similarities between the reaction mechanisms of sulfate-sulfide isotope exchange and 485 the multistep change in oxidative state of sulfur during the TSR process (Ohmoto and Lasaga, 486 1982; Goldstein and Aizenshtat, 1994). The kinetics of both reactions are strongly dependent 487 upon temperature, $\mathrm{pH}$ and sulfate-sulfide concentrations, because these parameters play a 488 primary role on the speciation and concentration of the intermediate valence sulfur species, 489 which act as a bridge for electron transfer between sulfate and sulfide. We suggest that the rapid 490 formation of $\mathrm{S}_{3}{ }^{-}, \mathrm{S}_{\mathrm{n}}{ }^{2-}$ and $\mathrm{S}_{\mathrm{n}}{ }^{0}$ species is a stage allowing TSR and sulfur isotope exchange to 491 occur, and not thiosulfate, or polythionates as believed previously (e.g., Ohmoto and Lasaga, 492 1982). The rapid decrease of $\mathrm{S}_{3}{ }^{-}$and $\mathrm{S}_{\mathrm{n}}{ }^{2-}$ concentration at $\mathrm{pH}$ above 6 at $200^{\circ} \mathrm{C}$ (Fig. $8 \mathrm{~d}$; Chu et 493 al., 2004) reflect well the decrease of the reaction rate of sulfate-sulfide isotope exchange and 494 TSR under alkaline condition. Under strongly acidic condition, it is probable that $\mathrm{S}_{\mathrm{n}}{ }^{0}$ together 495 with sulfate speciation (dominated by $\mathrm{HSO}_{4}{ }^{-}$a non-symmetric, so more reactive species) and the 496 abundance of proton (TSR imply a net consumption of $\mathrm{H}^{+}$, see Equation 4) explain the increase 497 of the TSR reaction rate (Truche et al., 2009; Pokrovski and Dubessy, 2015). These intermediate 498 valence sulfur species may also facilitate electron transfer between carbon species and enhance 499 the rates of reaction between hydrocarbons, methane and $\mathrm{CO}_{2}$ (Seewald, 2003).

500 Despite its complexity, TSR is a common reaction in numerous geological settings and 501 represents a key geochemical process in many environments where mass transfer and chemical 502 fractionation are involved. The high concentrations of these intermediate valence $\mathrm{S}$ species at $\mathrm{T}$ 
$503>100^{\circ} \mathrm{C}$ place significant constraints on the formation of sour gas fields (Machel, 2001; Cai et 504 al., 2003) and sulfide ore deposits (e.g. Mississippi Valley-type deposits, Volcanogenic-Massive 505 Sulfide deposits) where reduced sulfur originates from TSR (Huston et al., 2001; Thom and 506 Anderson, 2008). In geologic conditions, bacterial sulfate reduction at the earliest stage of 507 diagenesis, or the thermal decomposition of sulfur bearing organic compounds, or fluid mixing 508 with sulfide-rich solution, or elemental sulfur disproportionation may provide the necessary 509 reduced sulfur to initiate TSR at $\mathrm{T}>100^{\circ} \mathrm{C}$ (Fig. 9; Machel, 2001). The TSR process itself may 510 occur under physico-chemical conditions that enhance the stability and concentration of $\mathrm{S}_{3}{ }^{-}$and $511 \mathrm{~S}_{\mathrm{n}}^{-2}\left( \pm \mathrm{S}_{\mathrm{n}}{ }^{0}\right)$ species: high sulfate-sulfide concentration, $\mathrm{T}>100^{\circ} \mathrm{C}$, and circum-neutral $\mathrm{pH}$ 512 conditions. The direct effect of $\mathrm{S}_{3}{ }^{-}$and polymeric $\mathrm{S}$ species on base metal solubility (e.g. $\mathrm{Pb}, \mathrm{Zn}$, $513 \mathrm{Cu}$ ) were only broadly estimated by Pokrovski et al. (2015) but remains to be more evaluated.

514 The presence of non-negligible concentrations of $\mathrm{S}_{3}{ }^{-}$and polymeric species in deep 515 sedimentary brines may also have important consequence for petroleum alteration and 516 organosulfur compounds (OSCs) formation during the TSR process (Seewald, 2001 and 2003; 517 Amrani, 2014). There is currently a significant research effort to document the effect of TSR on 518 non-volatile high molecular weight aromatic and polar organic species (e.g. Walters et al., 2015; 519 Meshoulam et al., 2016). It has been suggested that $\mathrm{H}_{2} \mathrm{~S}$ reacts with hydrocarbons to form OSCs 520 (e.g., thiols, sulfides, thiophenes, and condensed thiophenes) that in turn catalyze TSR (Amrani 521 et al., 2008; Zhang et al., 2008). Intermediate oxidation-state S species such as elemental S, 522 polysulfides, sulfites or thiosulfates have been also proposed as possible sources for OSCs 523 formation during TSR (Goldstein and Aizenshtat, 1994; Lewan, 1998). However, elemental S 524 and thiosulfates are poor nucleophiles and break down into sulfate and sulfide at $\mathrm{T}>100^{\circ} \mathrm{C}$, 525 which make them unfavorable candidate for the reaction with organic matter under deep 
526 sedimentary conditions. By contrast, the strong nucleophile character of polysulfides and the $\mathrm{S}_{3}{ }^{-}$

527 ion (Chivers and Elder, 2013), suggests that these species are more prone to react with

528 hydrocarbons than $\mathrm{H}_{2} \mathrm{~S}$ or elemental S. Sulfur isotope fractionation associated with the formation

529 of OSCs is a potential tracer for the occurrence and extent of TSR (Amrani, 2014; Gvirtzman et

530 al., 2015; Cai et al., 2016; Meshoulam et al., 2016). However, important mechanistic details

531 about the overall TSR process are still missing and prevent full explanation of the sulfur isotope

532 records. We suggest that polymeric sulfur species and, in particular, the $\mathrm{S}_{3}{ }^{-}$ions should be

533 considered in the sulfur isotopic fractionation model to bring back together laboratory and field

534 observations.

535 6. Conclusions and perspectives

536 The main conclusions from this study are:

537 1. We reveal for the first time the formation of the trisulfur $\mathrm{S}_{3}{ }^{-}$ion and other polymeric $\mathrm{S}$ 538 species $\left(\mathrm{S}_{\mathrm{n}}{ }^{2-} \pm \mathrm{S}_{\mathrm{n}}{ }^{0}\right)$ at $\mathrm{T}>100^{\circ} \mathrm{C}$ in natural fluids from typical deeply buried 539 sedimentary environment where TSR occurred.

5402 . The concentration of $\mathrm{S}_{3}^{-}$ion can reach $2800 \mathrm{ppm}$ at $300^{\circ} \mathrm{C}$ in fluid inclusions 541 containing sulfate-sulfide concentration above $0.1 \mathrm{~mol} / \mathrm{kg}_{\mathrm{H} 2 \mathrm{O}}$.

542 3. This work confirms the previous findings that $\mathrm{S}_{3}{ }^{-}$is a major stable intermediate 543 valence S species involved in the reaction path of TSR. The onset temperature of TSR in nature around $100-140^{\circ} \mathrm{C}$ corresponds remarkably well to the rise of $\mathrm{S}_{3}{ }^{-}$and other polymeric $\mathrm{S}$ species concentrations in the fluid inclusions.

4. The TSR process itself occurs under physico-chemical conditions that enhance the stability and concentration of $S_{3}{ }^{-}$and $S_{n}{ }^{2-}\left( \pm S_{n}{ }^{0}\right)$ species: high sulfate-sulfide concentration, $\mathrm{T} \geq 100^{\circ} \mathrm{C}$, and circum-neutral $\mathrm{pH}$ conditions. 
5. This study opens up new perspectives on TSR isotopic record and into the S-chain radical reactions involved in organic-inorganic interactions, where sulfur speciation play a key role.

552 The discovery of the trisulfur $\mathrm{S}_{3}{ }^{-}$ion and other polymeric $\mathrm{S}$ species, in natural geological fluid 553 at $\mathrm{T} \geq 100^{\circ} \mathrm{C}$, may also encourage new investigations on sulfur speciation in natural geological

554 fluids associated with metamorphism, mid-oceanic ridge hydrothermal fluid circulation and 555 magmatic/porphyry settings where sulfate and sulfide often coexist.

\section{Acknowledgements}

557 This work was funded by LABEX ANR-10-LABX-21-01 Ressources21 (Strategic metal 558 resources of the $21^{\text {st }}$ Century) and the French Ministry of Higher Education and Research. The 559 authors are extremely grateful to M.C. Jodin-Caumon and P. Robert for technical assistance 560 during Raman spectroscopic analysis and O. Barrès during Infrared spectroscopic analysis. The 561 paper benefited greatly from the review provided by G. Pokrovski, H. Ohmoto and one 562 anonymous reviewer. We thank M. Böttcher for editorial support.

\section{References}

564 Amrani, A., Zhang, T., Ma, Q., Ellis, G.S., Tang, Y., 2008. The role of labile Sulphur compounds in thermal sulphate reduction. Geochim. Cosmochim. Acta 72, 2960-2972.

566 Amrani, A., 2014. Organosulfur compounds: molecular and isotopic evolution from biota to oil and gas. Annu. Rev. Earth Planet. Sci. 42, 733-768.

568 Barnes, H.L., 1997. Geochemistry of Hydrothermal Ore Deposits, Wiley, New York.

569 Basuki, N.I., Taylor, B.E., Spooner, E.T.C., 2008. Sulfur isotope evidence for thermochemical 570 reduction of dissolved sulfate in Mississippi Valley-Type zinc-lead mineralization, Bongara 571 Area, Northern Peru. Econ. Geol. 103, 783-799. 
572 Bodnar, R.J., 2003. Reequilibration of fluid inclusions: Fluid inclusions: Analysis and 573 interpretation. In Samson, I., Anderson, A., and Marshall, D., eds, Mineralogical Association 574 of Canada, Short Course 32, 213-230.

575 Bodnar, R.J., Bethke, P.M., 1984. Systematics of stretching of fluid inclusions I: Fluorite and 576 sphalerite at 1 atmosphere confining pressure. Econ. Geol. 79, 141-161.

577 Boiron, M-C., Moissette, A., Cathelineau, M., Banks, D., Monnin, C., and Dubessy, J., 1999. 578 Detailed determination of palaeofluid chemistry: an integrated study of sulphate-volatile rich brines and aquo-carbonic fluids in quartz veins from Ouro Fino (Brazil). Chem. Geol. 154,

Boulègue, J., 1978. Metastable sulfur species and trace metals (Mn, $\mathrm{Fe}, \mathrm{Cu}, \mathrm{Zn}, \mathrm{Cd}, \mathrm{Pb}$ ) in hot brines from the French Dogger. Am. J. Sci. 278, 1394-1411.

Boulègue, J., Michard, G., 1978. Constantes de formation des ions polysulfurés $\mathrm{S}_{6}{ }^{2-}, \mathrm{S}_{5}{ }^{2-}$ et $\mathrm{S}_{4}{ }^{2-}$ en phase aqueuse. J. Fr. Hydrologie 9, 27-34 (in french).

Cai, C., Amrani, A., Worden, R.H., Xiao, Q., Wang, T., Gvirtzman, Z., Li, H., Said-Ahmad, W., Jia, L., 2016. Sulfur isotopic compositions of individual organosulfur compounds and their genetic links in the Lower Paleozoic petroleum pools of the Tarim Basin, NW China. Geochim. Cosmochim. Acta 182, 88-108.

Cai, C., Worden, R.H., Bottrell, S.H., Wang, L., Yang, C., 2003. Thermochemical sulphate reduction and the generation of hydrogen sulphide and thiols (mercaptans) in Triassic carbonate reservoirs from the Sichuan Basin, China. Chem. Geol. 202, 39-57.

Caumon, M.C, Dubessy, J., Robert, P., Tarantola, A., 2013. Fused-silica capillary capsules (FSCCs) as reference synthetic aqueous fluid inclusions to determine chlorinity by Raman spectroscopy. Eur. J. Mineral. 25, 755-763. 
595 Chivers, T., Elder, P.J.W., 2013. Ubiquitous trisulfur radical anion: fundamentals and 596 applications in materials science, electrochemistry, analytical chemistry and geochemistry. 597 Chem. Soc. Rev. 42, 5996-6005.

598 Chivers, T., Lau, C., 1982. Raman spectroscopic identification of the $\mathrm{S}_{4} \mathrm{~N}^{-}$and $\mathrm{S}_{3}{ }^{-}$ions in blue 599 solutions of sulfur in liquid ammonia. Inorg. Chem. 21, 453-455.

600 Chou, I-M., Song, Y., Burruss, R.C., 2008. A new method for synthesizing fluid inclusions in 601 fused silica capillaries containing organic and inorganic material. Geochim. Cosmochim. $602 \quad$ Acta 72, 5217-5231.

603 Chu, X., Ohmoto, H., Cole, D.R., 2004. Kinetics of sulfur isotope exchange between aqueous 604 sulfide and thiosulfate involving intra- and intermolecular reactions at hydrothermal 605 conditions. Chem. Geol. 211, 217-235.

606 Collins, A.G., 1975. Geochemistry of oilfield waters. Elsevier, Amsterdam, The Netherlands, $607 \quad 496 \mathrm{p}$.

608 Cross, M.M., Manning, D.A.C., Bottrell, S.H., Worden, R.H., 2004. Thermochemical sulphate 609 reduction (TSR): experimental determination of reactions kinetics and implications of the 610 observed reaction rates for petroleum reservoirs. Org. Geochem. 35, 393-404.

611 Debelmas, J., Desmons, J., Ellenberger, F., Goffé, B., Fabre, J., Jaillard, E., and Pachoud, A., 612 1989a. Notice explicative de la feuille Modane. B.R.G.M., scale 1/50 000, 1 sheet, 53 p. text 613 (in french).

614 Debelmas, J., Desmons, J., Ellenberger, F., Goffé, B., Fabre, J., 1989b. Carte géologique de la $615 \quad$ France, feuille de Modane. B.R.G.M., scale 1/50000. 
616 Dubessy, J., Audeoud, D., Wilkins, R., Kosztolanyi, C., 1982. The use of the Raman microprobe 617 mole in the determination of the electrolytes dissolved in the aqueous phase of fluid 618 inclusions. Chem. Geol. 37, 137-150.

619 Dubessy, J., Leisen, J.P., Lhomme, T., Pironon, J., 2008. Measurements of concentration ratios 620 of polysulfanes in mixtures solvent-sulfur-sulfanes. Unpublished rapport (in French).

621 Dubessy, J., Lhomme, T., Boiron, M-C., Rull, F., 2002. Determination of chlorinity in aqueous 622 fluids using Raman spectroscopy of the stretching band of water at room temperature: 623 Application to fluid inclusions. Appl. Spectrosc. 56, 99-106.

624 Gabalda, S., Beyssac, O., Jolivet, L., Agard, P., Chopin, C., 2009. Thermal structure of a fossil 625 subduction wedge in the Western Alps. Terra Nova 21, 28-34.

626 Giggenbach, W., 1968. On the nature of the blue solutions of sulfur. J. Inorg. Nucl. Chem. 30, 627 3189-3201.

628 Giggenbach, W.F., 1974. Equilibrium involving polysulphide ions in aqueous sulphide solutions up to $240^{\circ} \mathrm{C}$. Inorg. Chem. $13,1724-1730$.

630 Goldhaber, M.B., Orr, W.L., 1995. Kinetic controls on thermochemical sulphate reduction as a 631 source of sedimentary $\mathrm{H}_{2} \mathrm{~S}$. In: Vairavamurthy, M.A., Schoonen, M.A.A. (Eds.), 632 Geochemical Transformations of Sedimentary Sulphur. American Chemical Society.

633 Goldstein, T.P., Aizenshtat, Z., 1994. Thermochemical sulfate reduction: A review. J. Therm. Anal. 42, 241-290.

635 Gvirtzman, Z., Said-Ahmad, W., Ellis, G.S., Hill, R.J., Moldowan, J.M., Wei, Z., Amrani, A., 636 2015. Compound-specific sulfur isotope analysis of thiadiamondoids of oils from the 637 Smackover Formation, USA. Geochim. Cosmochim. Acta 167, 144-161. 
638 Haas, J.L., 1976. Physical properties of the coexisting phases and thermochemical properties of the $\mathrm{H} 2 \mathrm{O}$ component in boiling $\mathrm{NaCl}$ solutions. U.S.G.S. Bulletin 1421-A, $73 \mathrm{p}$.

Helgeson, H.C., Kirkham, D.H., Flowers, G.C., 1981. Theoretical prediction of the

Huston, D.L., Brauhart, C.W., Drieberg, S.L., Davidson, G.J., Groves, D.I., 2001. Metal leaching Horita, J., Zimmermann, H., Holland, H.D., 2002. Chemical evolution of seawater during the Phanerozoic: Implications from the record of marine evaporites. Geochim. Cosmochim. Acta 66, 3733-3756.

$$
\text { thermodynamic behavior of aqueous electolytes at high pressures and temperatures: IV. }
$$
Calculation of activity coefficients, osmotic coefficients, and apparent molal and standard and relative partial molal properties to $600^{\circ} \mathrm{C}$ and 5kb. Am. J. Sci. 281, 1249-1516.

Heydari, E., Moore, C.H., 1989. Burial diagenesis and thermochemical sulfate reduction, Smackover Formation, southeastern Mississippi salt basin. Geology, 17, 1080-1084.

656 Johnson, J.W., Oelkers, E.H., Helgeson, H.C., 1992. SUPCRT92: A software package for 657 calculating the standard molal thermodynamic properties of minerals, gases, aqueous and inorganic sulfate reduction in volcanic-hosted massive sulfide minerals systems: Evidence from the paleo-Archean Panorama district, Western Australia. Geology 29, 687690.

Jacquemet, N., Guillaume, D., Zwick, A., Pokrovski, G.S., 2014. In situ Raman spectroscopy identification of the $\mathrm{S}_{3}{ }^{-}$ion in S-rich hydrothermal fluids from synthetic fluid inclusions. Am. Mineral. 99, 1109-1118. species, and reactions from 1 to 5000 bar and to 0 to $1000^{\circ} \mathrm{C}$. Comput. Geosci. 18, 899-947.

Kaasalainen, H., Stefánsson, A., 2011. Sulfur speciation in natural hydrothermal waters, Iceland. Geochim. Cosmochim. Acta 75, 2777-2791. 
661 Kamyshny, A., Jr., Gun, J., Rizkov, D., Voitsekovski, T., Lev, O., 2007. Equilibrium distribution 662 of polysulfide ions in aqueous solutions at different temperatures by rapid single phase 663 derivatization. Environ. Sci. Technol. 41, 2395-2400.

664 Kamyshny, A., Jr., Zilberbrand, M., Ekeltchik, I., Voitsekovski, T., Gun, J., Lev, O., 2008. 665 Speciation of polysulfides and zerovalent sulfur in sulfide-rich water wells in Southern and 666 Central Israel. Aquat. Geochem. 14, 171-192.

667 Kiyosu, Y., Krouse, H.R., 1993. Thermochemical reduction and sulphur isotopic behavior of 668 sulfate by acetic-acid in the presence of native sulphur. Geochem. J. 27, 49.

669 Lanari, P., Guillot, S., Schwartz, S., Vidal, O., Tricart, P., Riel, N., Beyssac, O., 2012. 670 Diachronous evolution of the alpine continental subduction wedge: evidence from P-T 671 estimates in the Brianc, onnais Zone houillère (France - Western Alps). J. Geodyn. 56-57, 672 $39-54$.

673 Lewan, M.D., 1998. Sulphur-radical control on petroleum formation rates. Nature 391, 164-166.

674 Ma, Q., Ellis, G.S., Amrani, A., Zhang, T., Tang, Y., 2008. Theoretical study on the reactivity of 675 sulfates species with hydrocarbons. Geochim. Cosmochim. Acta 72, 4565-4576.

676 Machel, H.G., 2001. Bacterial and thermochemical sulfate reduction in diagenetic settings - old 677 and new insights. Sediment. Geol. 140, 143-175.

678 Mao, S., Duan, Z., 2008. The P,V,T, $\chi$ properties of binary aqueous chloride solutions up to $\mathrm{T}=$ 679 $573 \mathrm{~K}$ and $100 \mathrm{MPa}$. J. Chem. Thermodyn. 40, 1046-1063.

680 Mavrogenes, J.A., Bodnar, R.J., 1994. Hydrogen movement into and out of fluid inclusions in 681 quartz: Experimental evidence and geologic implications. Geochim. Cosmochim. Acta 58, $682 \quad 141-148$. 
Meshoulam, A., Ellis, G.S., Said Ahmad, W., Deev, A., Sessions, A.L., Tang, Y., Adkins, J.F., Jinzhong, L., Gilhooly III, W.P., Aizenshtat, Z., Amrani, A., 2016. Study of thermochemical sulfate reduction mechanism using compound specific sulfur isotope analysis. Geochim. Cosmochim. Acta 188, 73-92.

Millero, F.J., 1986. The thermodynamics and kinetics of the hydrogen sulfide system in natural waters. Mar. Chem. 18, 121-147.

Nordstrom, D.K., McCleskey, R.B., Ball, J.W., 2009. Sulfur geochemistry of hydrothermal waters in Yellowstone National Park: IV Acid-sulfate waters. Appl. Geochem. 24, 191-207.

Oduro, H., Harms, B., Sintim, H.O., Kaufman, A.J., Cody, G., Farquhar, J., 2011. Evidence of magnetic isotope effects during thermochemical sulfate reduction. Proc. Natl. Acad. Sci. U.S.A. $108,17635-17638$.

Ohmoto, H., Lasaga, A.C., 1982. Kinetics of reactions between aqueous sulfates and sulfides in hydrothermal systems. Geochim. Cosmochim. Acta 46, 1727-1745.

Orr, W.L., 1974. Changes in sulfur content and isotopic-ratios of sulfur during petroleum maturation - study of Big Horn Basin Paleozoic oils. AAPG Bulletin 58, 2295-2318.

Parkhurst, D.L., Appelo, C.A.J., 1999. User's guide to PHREEQC (version 2)- A computer program for speciation, batch-reaction, one-dimensional transport, and inverse geochemical calculations. U.S.G.S. Water-Res. Invest. Rep. 99-4259, Denver, Colorado, USA, 312 p.

Pitzer, K.S., Peiper, J.C., Busey, R.H., 1984. Thermodynamics properties of aqueous sodium chloride solutions. J. Phys. Chem. Ref. Data 13, 1-102.

Pokrovski, G.S., Dubessy, J., 2015. Stability and abundance of the trisulfur radical ion $\mathrm{S}_{3}{ }^{-}$in hydrothermal fluids. Earth Planet. Sci. Lett. 411, 298-309. 
Pokrovski, G.S., Dubrovinsky, L.S., 2011. The $\mathrm{S}_{3}{ }^{-}$ion is stable in geological fluids at elevated temperatures and pressures. Science 331, 1052-1054.

707 Pokrovski, G.S., Kokh, M.A., Guillaume, D., Borisova, A.Y., Gisquet, P., Hazemann, J-L.,

708 Lahera, E., Del Net, W., Proux, O., Testemale, D., Haigis, V., Jonchière, R., Seitsonen, A.P., 709 Ferlat, G., Vuilleumier, R., Saitta, A.M., Boiron, M-C., and Dubessy, J., 2015, Sulfur radical 710 species form gold deposits on Earth: Proc. Natl. Acad. Sci. U.S.A., 112, 13484-13489.

711 Richard L., Neuville N., Sterpenich J., Perfetti E. and Lacharpagne J.C., Thermodynamic 712 analysis of organic/inorganic reactions involving sulfur: implications for the sequestration of 713 H2S in carbonate reservoirs, Oil Gas Sci. Technol., 60, 275-285.

714 Seewald, J.S., 2001. Aqueous geochemistry of low molecular weight hydrocarbons at elevated 715 temperatures and pressures: Constraints from mineral buffered laboratory experiments. 716 Geochim. Cosmochim. Acta 65, 1641-1664.

717 Seewald, J.S., 2003. Organic-inorganic interactions in petroleum-producing sedimentary basins. $718 \quad$ Nature 426, 327-333.

719 Servoss, R.R., Clark, H.M., 1957. Vibrational spectra of normal and isotopically labeled boric $720 \quad$ acid. J. Chem. Phys. 26, 1175-1178.

721 Steele-MacInnis, M., Bodnar, R.J., Naden, J., 2011. Numerical model to determine the 722 composition of $\mathrm{H} 2 \mathrm{O}-\mathrm{NaCl}-\mathrm{CaCl} 2$ fluid inclusions based on microthermometric and 723 microanalytical data. Geochim. Cosmochim. Acta 75, 21-40.

724 Steudel, R., 2003. Elemental Sulfur and Sulfur-rich Compounds I, II. Springer, Berlin.

725 Strzerzynski, P., Guillot, S., Leloup, P.H., Arnaud, N., Vidal, O., Ledru, P., Courrioux, G., 726 Darmendrail, X., 2012. Tectono-metamorphic evolution of the Briançonnais zone (Modane- 
Aussois and Southern Vanoise units, Lyon Turin transect, Western Alps). J. Geodyn. 56-57,

729 Takano, B., 1987. Correlation of volcanic activity with sulfur oxyanion speciation in a crater $730 \quad$ lake. Science 235, 1633-1635.

731 Takano, B., Ohsawa, S., Glover, R.B., 1994. Surveillance of Ruapehu Crater, New Zealand, by 732 aqueous polythionates. J. Volcanol. Geotherm. Res. 60, 29-57.

733 Thom, J., Anderson, G.M., 2008. The role of thermochemical sulfate reduction in the origin of 734 Mississippi Valley-Type deposits. I. Experiemental results. Geofluids 8, 16-26.

735 Truche, L., Bazarkina, E.F., Barré, G., Thomassot, E., Berger, G., Dubessy, J., Robert, P., 2014. 736 The role of $\mathrm{S}_{3}^{-}$ion in thermochemical sulphate reduction: Geological and geochemical 737 implications. Earth Planet. Sci. Lett. 396, 190-200.

738 Truche, L., Berger, G., Destrigneville, C., Pages, A., Guillaume, D., Giffaut, E., Jacquot, E., 739 2009. Experimental reduction of aqueous sulphate by hydrogen under hydrothermal 740 conditions: implication for the nuclear waste storage. Geochim. Cosmochim. Acta 73, 4824$741 \quad 4835$.

742 Uyama, F., Chiba, H., Kusakabe, M., Sakai, H., 1985. Sulfur isotope exchange reactions in the 743 aqueous system: thiosulfate-sulfide-sulfate at hydrothermal temperature. Geochem. J. 19, $744 \quad 301-315$.

745 Vanko, D.A., Bach, W., 2005. Heating and freezing experiments on aqueous fluid inclusions in 746 anhydrite: recognition and effects of stretching and the low-temperature formation of 747 gypsum. Chem. Geol. 223, 35-45.

748 Veldeman, E., Van't dac, L., Gijbels, R., Pentcheva, E., 1991. Sulfur species and associated trace 749 elements in south-west Bulgarian thermal waters. Appl. Geochem. 6, 49-62. 
Walters, C.C., Wang, F.C., Qian, K., Wu, C., Mennito, A.S., Wei, Z., 2015. Petroleum alteration by thermochemical sulfate reduction - A comprehensive molecular study of aromatic hydrocarbons and polar compounds. Geochim. Cosmochim. Acta 153, 37-71.

753 Wang, C.H., Wright, R.B., 1973. Effect of density on the Raman scattering of molecular fluids. I. 754 A detailed study of the scattering polarization, intensity, frequency shift, and spectral shape 755 in gaseous $\mathrm{N}_{2}$. J. Chem. Phys. 59, 1706-1712.

756 Watanabe, Y., Farquhar, J., Ohmoto, H., 2009. Anomalous fractionations of sulfur isotopes 757 during thermochemical sulfate reduction. Science 324, 370-373.

758 Webster, J.G., 1987. Thiosulfate in surficial geothermal waters, North Island, New Zealand. 759 Appl. Geochem. 2, 579-584.

760 Williamson, M.A., Rimstidt, J.D., 1992. Correlation between structure and thermodynamic 761 properties of aqueous sulfur species. Geochim. Cosmochim. Acta 56, 3867-3880.

762 Worden, R.H., Smalley, P.C., 1996. $\mathrm{H}_{2}$ S-producing reactions in deep carbonate gas reservoirs: 763 Khuff Formation, Abu Dhabi. Chem. Geol. 133, 157-171.

764 Worden, R.H., Smalley, P.C., Barclay, S.A., 2003. $\mathrm{H}_{2} \mathrm{~S}$ and diagenetic pyrite in North Sea 765 sandstones: due to TSR or organic sulphur compound cracking?. J. Geochem. Explor. 78-79, $766 \quad 487-491$.

767 Xu, Y., Schoonen, M.A.A., Nordstrom, D.K., Cunningham, K.M., Ball, J.W., 1998. Sulfur 768 geochemistry of hydrothermal waters in Yellowstone National Park, Wyoming, USA: I. 769 Origin of thiosulfate in selected hot spring waters. Geochim. Cosmochim. Acta 62, 3729770 3743. 
771 Yuan, S., Chou, I-M., Burruss, R.C., Wang, X., Li, J., 2013. Disproportionation and

772 thermochemical sulfate reduction reactions in $\mathrm{S}-\mathrm{H}_{2} \mathrm{O}-\mathrm{CH}_{4}$ and $\mathrm{S}-\mathrm{D}_{2} \mathrm{O}-\mathrm{CH}_{4}$ systems from

773200 to $340{ }^{\circ} \mathrm{C}$ at elevated pressures. Geochim. Cosmochim. Acta 118, 263-275.

774 Zhang, T., Amrani, A., Ellis, G.S., Ma, Q., Tang, Y., 2008. Experimental investigation on

775 thermochemical sulphate reduction by $\mathrm{H}_{2} \mathrm{~S}$ initiation. Geochim. Cosmochim. Acta 72, 3518$776 \quad 3530$.

777 Appendix A. Supplementary material

778 Supplementary information is available in the attached file.

779

780 TABLE

781 Table 1. Sulfur species concentrations (mol/ $\left.\mathrm{kg}_{\mathrm{H} 2 \mathrm{O}}\right)$ measured in natural fluid inclusions 782 representative for TSR processes in the Arc Valley (French Alps).

\section{FIGURE CAPTIONS}

784 Fig. 1. Simplified geological map of the Arc Valley (France) with the sampling locations 785 (modified from Debelmas et al., 1989b).

786 Fig. 2. (a) Typical outcrops of the sampled Carnian evaporite from the Arc Valley (France) 787 showing schistosity in the anhydrite and up to $2 \mathrm{~m}$ in diameter dolomitc "boudins". (b) 788 Uncolored to purple fluorite crystals in association with native sulfur disseminated in anhydrite 789 or located in fractures affecting the cryptocrystalline dolomite. (c) Native sulfur occurrence in 790 association with anhydrite and dolomite. (d) Pyrite associated to anhydrite and crystalline white 791 dolomite. Abbreviations: $\mathrm{CcD}=$ cryptocrystalline dolomite; Anh = anhydrite; $\mathrm{S}=$ elemental 792 sulfur; $\mathrm{Fl}=$ fluorite; $\mathrm{WD}=$ white dolomite; $\mathrm{Py}=$ pyrite. 
793 Fig. 3. Microthermometry results of fluid inclusions from the Arc Valley (France). (a) Histogram

794 of homogenization temperatures (Th). (b) Histogram of last ice melting temperatures (Tm ice).

795 Fig. 4. Raman calibration coefficients $\left(\mathrm{k}_{\mathrm{i}}\right)$ for the $514 \mathrm{~nm}$ laser excitation for sulfur species as

796 function of temperature $\left({ }^{\circ} \mathrm{C}\right)$. (a) Calibration coefficients for the major sulfur species as deduced

797 from standard solutions. Note the slight effect of salinity on the calibration coefficients of $\mathrm{SO}_{4}{ }^{2-}$.

798 (b) Calibration coefficients for $\mathrm{S}_{3}{ }^{-}\left(\mathrm{k}_{\mathrm{S} 3}\right.$-) deduced and used in this study and $\mathrm{k}_{\mathrm{S} 3}$ - from Pokrovski

799 and Dubessy (2015). Calculations are done according to equation 3 assuming the same

800 temperature dependence as for $\mathrm{H}_{2} \mathrm{~S}$.

801 Fig. 5. Raman spectra of the several phases in the fluid inclusions at room temperature. (a)

802 Typical Raman spectrum of the vapor phase of fluid inclusions hosted in fluorite. $\mathrm{CO}_{2}$ and $\mathrm{H}_{2} \mathrm{~S}$

803 are the main component of the gas phase. Raman spectra were acquired using the $514 \mathrm{~nm}$ (green)

$804 \mathrm{Ar}^{+}$laser excitation. $\mathrm{N}_{2}, \mathrm{CH}_{4}$ and $\mathrm{H}_{2}$ are also present. The broad, but weakly intense, $\mathrm{O}-\mathrm{H}$

805 stretching band of liquid water between $2800-3700 \mathrm{~cm}^{-1}$ is also visible on this Raman spectrum,

806 because the gas bubble moves slightly during the measurements, and the liquid phase may be

807 impacted by the laser beam. (b) Zoom on the $2280-2380 \mathrm{~cm}^{-1}$ region and comparison with a

808 Raman spectrum of air (green curve). The splitting of the $\mathrm{N}_{2}$ band (red curve) demonstrates the

809 presence of $\mathrm{N}_{2}$ under pressure in the gas phase of the fluid inclusion (see above). (c) Typical

810 Raman spectra of the aqueous phase of fluid inclusions hosted in quartz and fluorite. Note that

811 the composition of fluid inclusions is similar whatever the host mineral. (d) Our measurement

812 allows resolving the contribution of $\mathrm{HS}^{-}$and $\mathrm{H}_{2} \mathrm{~S}$ stretching vibration (2570 and $2582 \mathrm{~cm}^{-1}$,

813 respectively) in the Raman peak located at $2400-2700 \mathrm{~cm}^{-1}$. (e), (f) and (g) Raman spectra of the

814 solids phases observed in the fluid inclusions hosted in fluorite and comparison with their 
815 reference in the RRUFF database (http://rruff.info/). Native sulfur spherule is always observed.

816 (e) Anhydrite, (f) calcite and (g) celestine are also observed in few fluid inclusions.

817 Fig. 6. Raman spectra of the aqueous phase of fluid inclusions hosted in fluorite (a) and quartz (b

818 and c) from the Carnian evaporite (French Alps) recorded at 25 to $300^{\circ} \mathrm{C}$. Vertical dashed lines

819 indicate the vibration mode ( $v=$ stretching, $\delta=$ bending $)$ and position of major Raman peaks for

820 the respective species in the inclusion. Stars indicate the host mineral peaks.

821 Fig. 7. Temperature evolution of sulfur speciation in natural fluid inclusions from the Carnian

822 evaporites formation (French Alps). At high temperature, trisulfur radical ion $\mathrm{S}_{3}^{-}$(blue circles)

823 and $\mathrm{S}_{\mathrm{n}}^{2-} \pm \mathrm{S}_{\mathrm{n}}{ }^{0}$ (estimated in grey shaded area) attain significant concentrations. During cooling,

824 their concentrations drop and only sulfates and sulfides are detected at $25^{\circ} \mathrm{C}$.

825 Fig. 8. Thermodynamic modeling of sulfur speciation as a function of (a) temperature at $\mathrm{pH} \sim 5$

826 (buffered by fluid equilibrium with calcite and 10 bar $\mathrm{CO}_{2}$ ) and redox controlled by

827 sulfate/sulfide equilibrium; (b) total $\mathrm{S}$ content at $200^{\circ} \mathrm{C}, \mathrm{pH}=5$ and $f\left(\mathrm{O}_{2}\right)$ buffered by the

828 hematite-magnetite (HM) assemblage; (c) oxygen fugacity at $200^{\circ} \mathrm{C}$ and $\mathrm{pH}=5$; (d) $\mathrm{pH}$ at $200^{\circ} \mathrm{C}$

829 and $f\left(\mathrm{O}_{2}\right)$ of $\mathrm{HM}$. All calculations (lines) are performed for Psat and fluid salinity of $4 \mathrm{~m} \mathrm{NaCl}$

830 and $1 \mathrm{~m} \mathrm{CaCl}_{2}$. Symbols represent $\mathrm{S}$ species concentrations measured in the natural fluid

831 inclusions. $\mathrm{PPM}=$ Pyrite-Pyrrhotite-Magnetite and HM = Hematite-Magnetite.

832 Fig. 9. Conceptual model of TSR and associated processes in deep sedimentary settings 833 highlighting the role of intermediate valence sulfur species. 


\section{$835 \quad$ Figure 1}

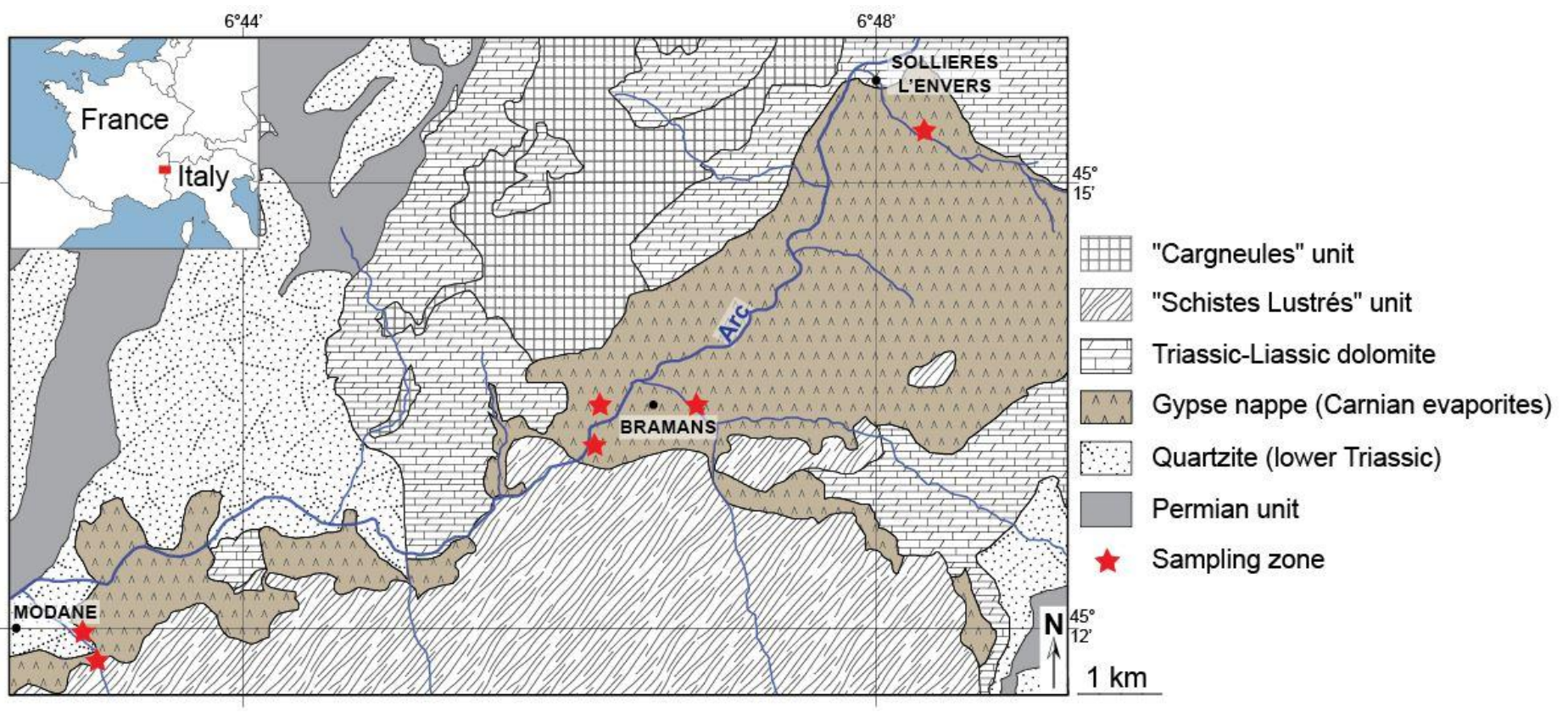

837 
$838 \quad$ Figure 2
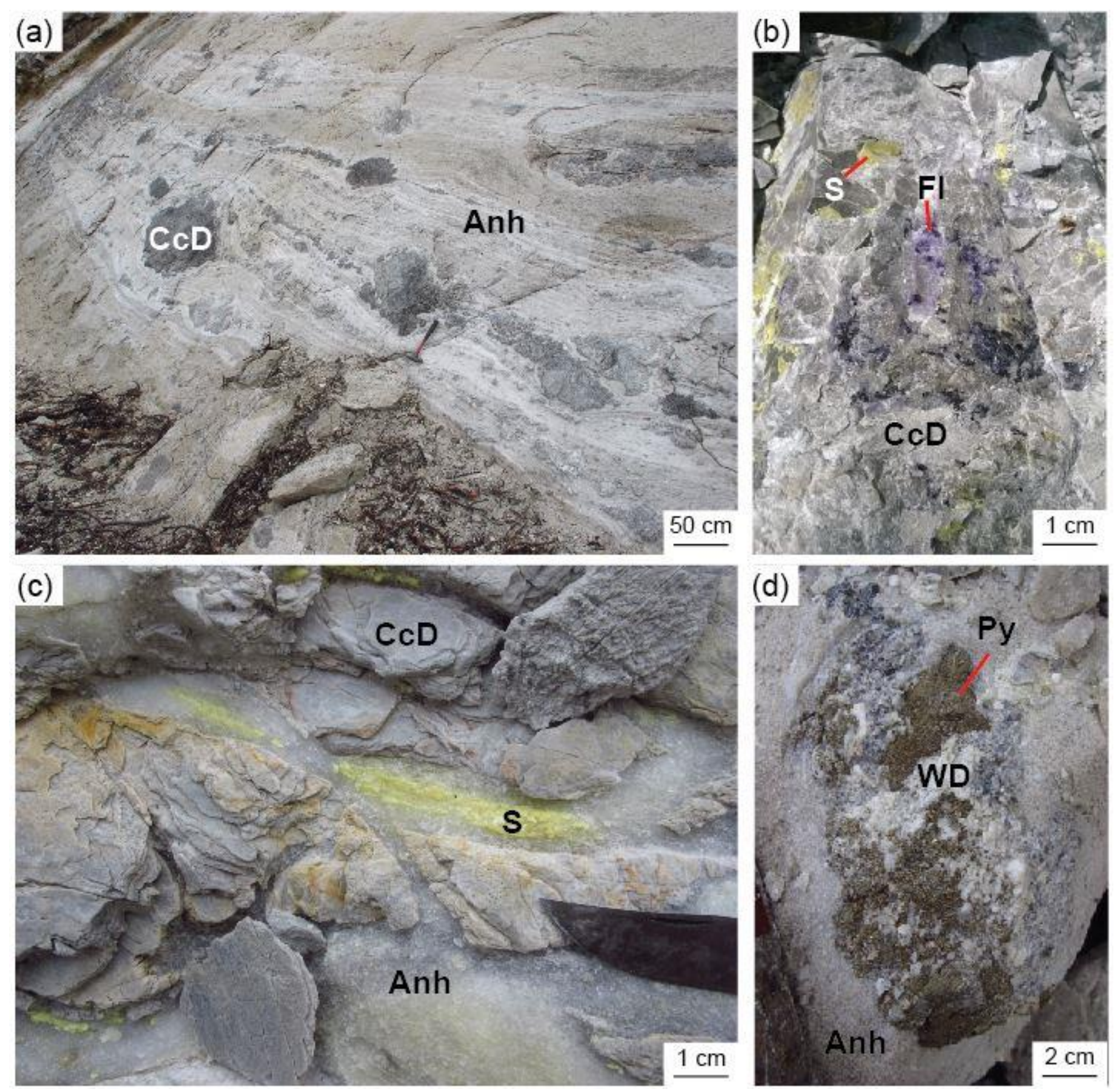
Figure 3
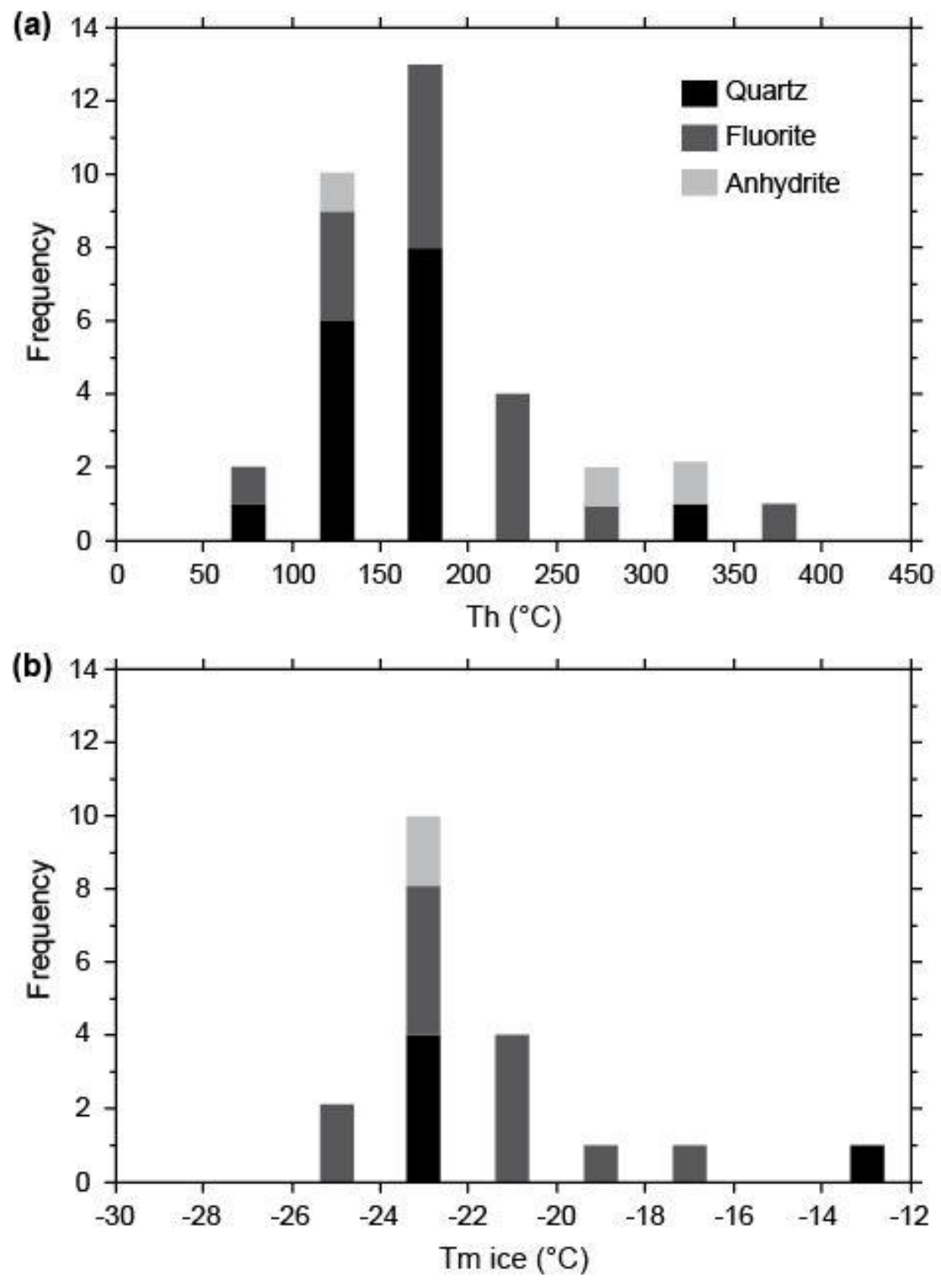

842

843 

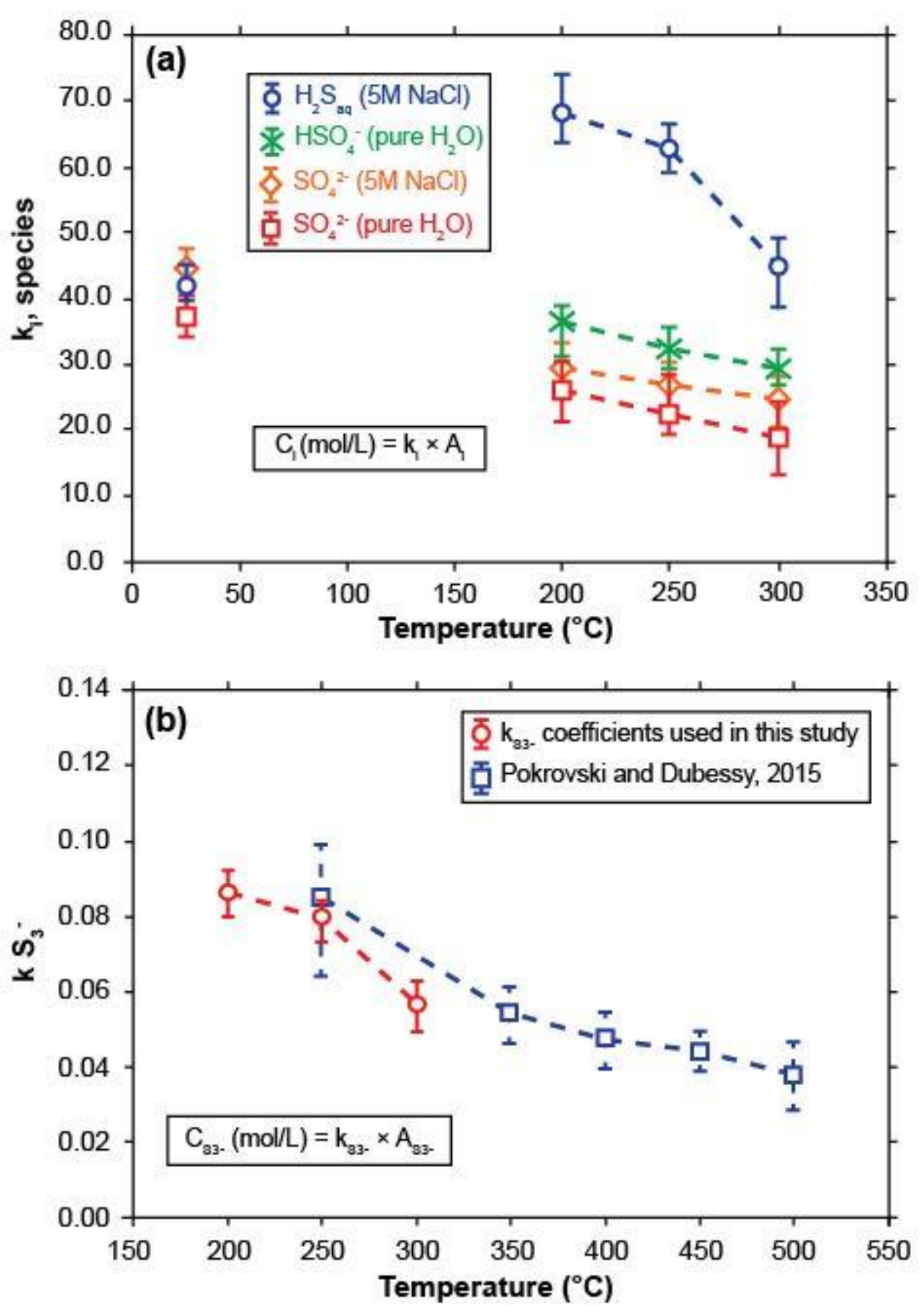

846 

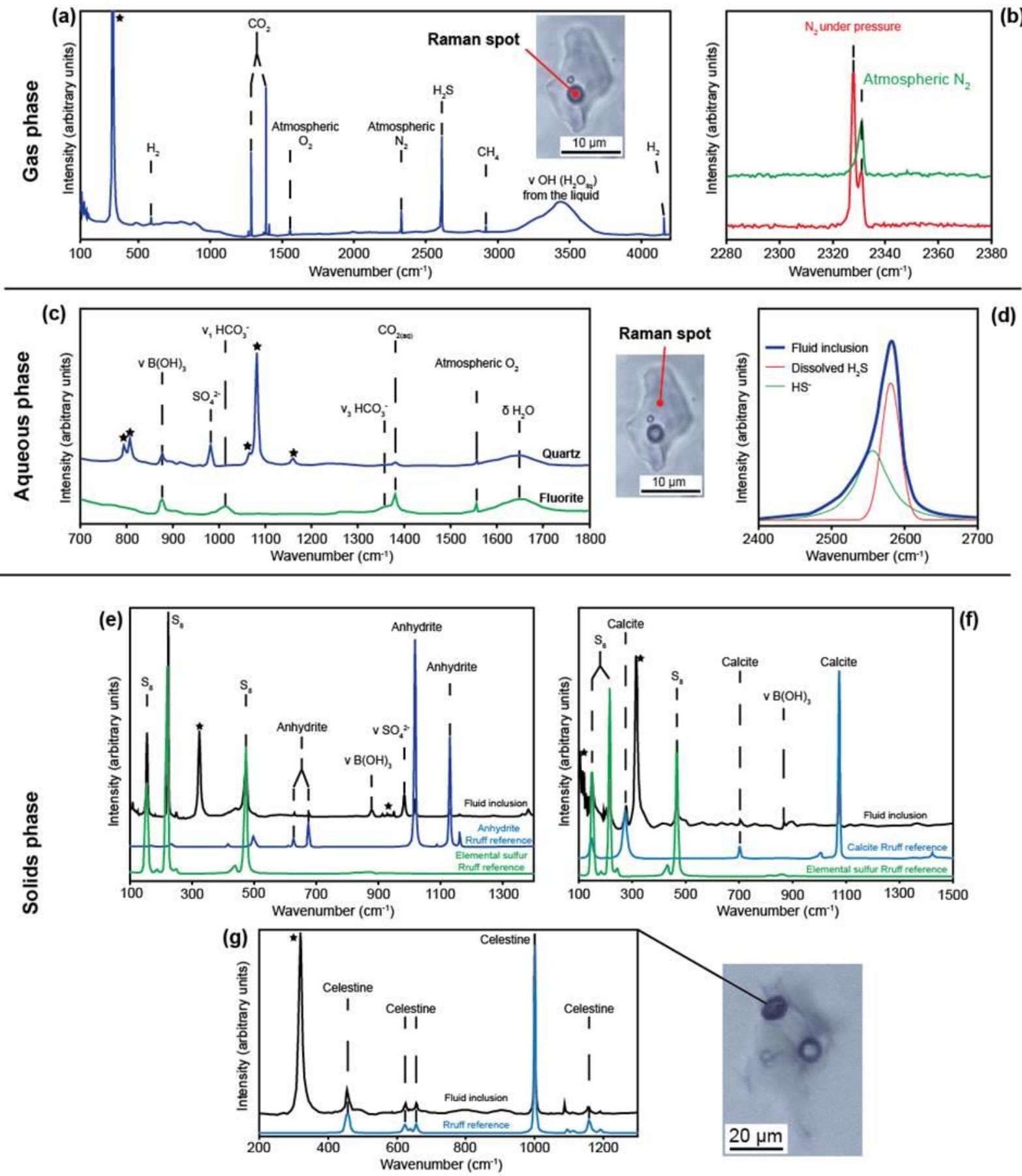
Figure 6
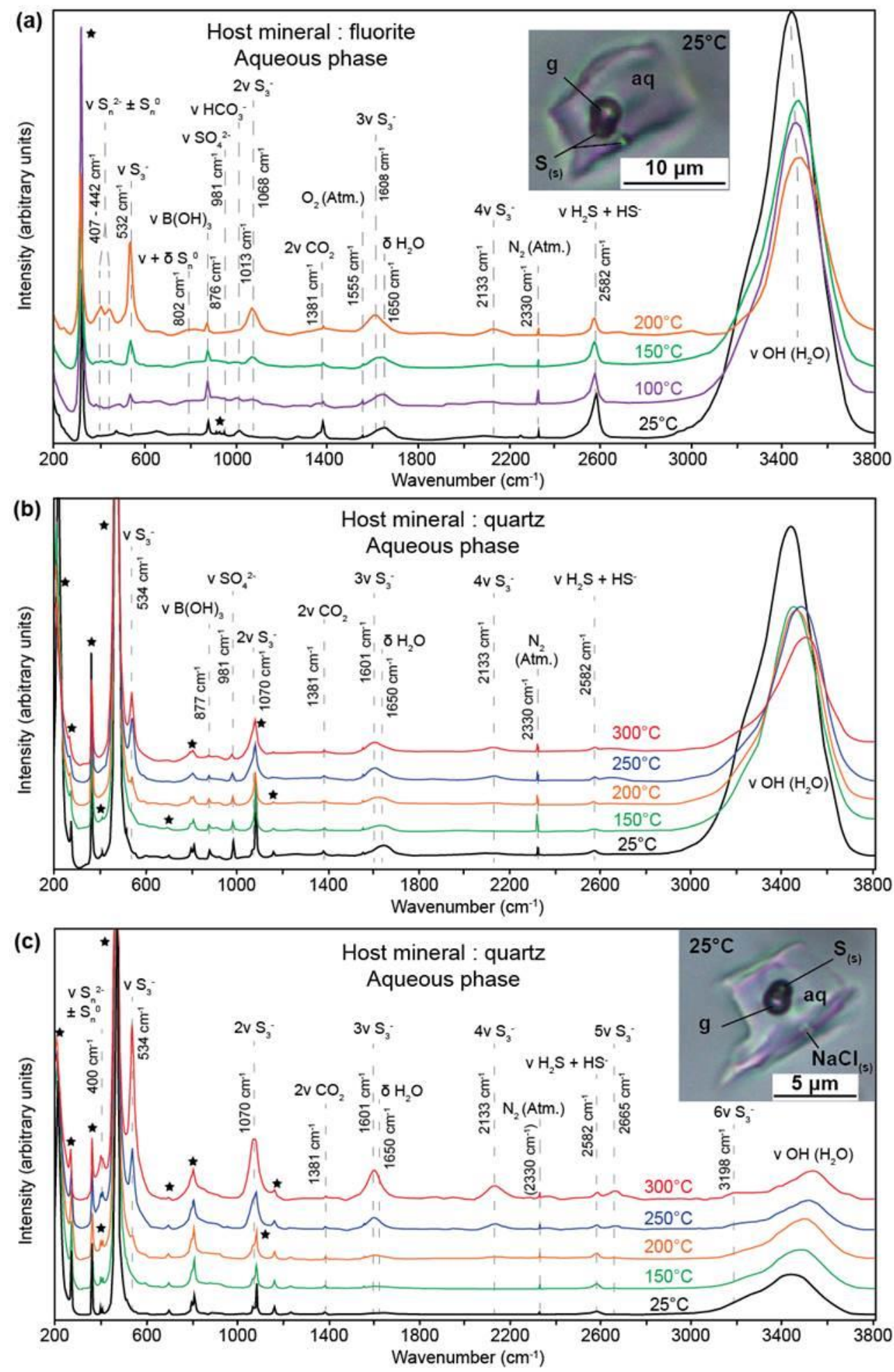
$853 \quad$ Figure 7

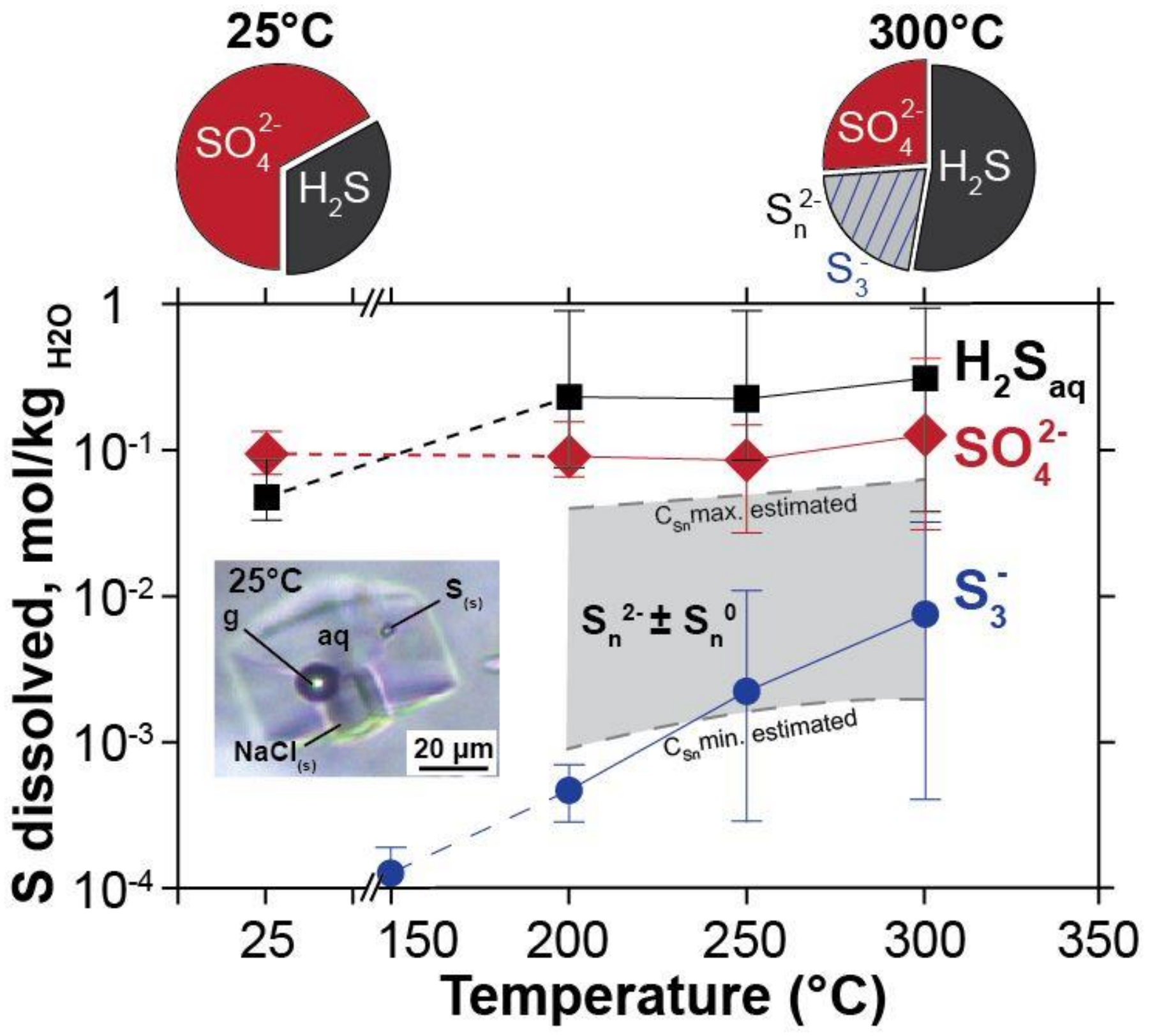

854 
(a) $S(6)=0.09 \mathrm{~m} ; \mathbf{S}(-2)=0.05 \mathrm{~m} ; 0.11 \mathrm{~m} \mathrm{~S}_{\text {eolld }} ; 3.3 \mathrm{~m} \mathrm{NaCl} ; 1.6 \mathrm{~m} \mathrm{CaCl}$ HM buffer; Calcite equilibrium; $\mathrm{P}\left(\mathrm{CO}_{2}\right)=10$ bar; $\mathrm{pH} \approx 5$

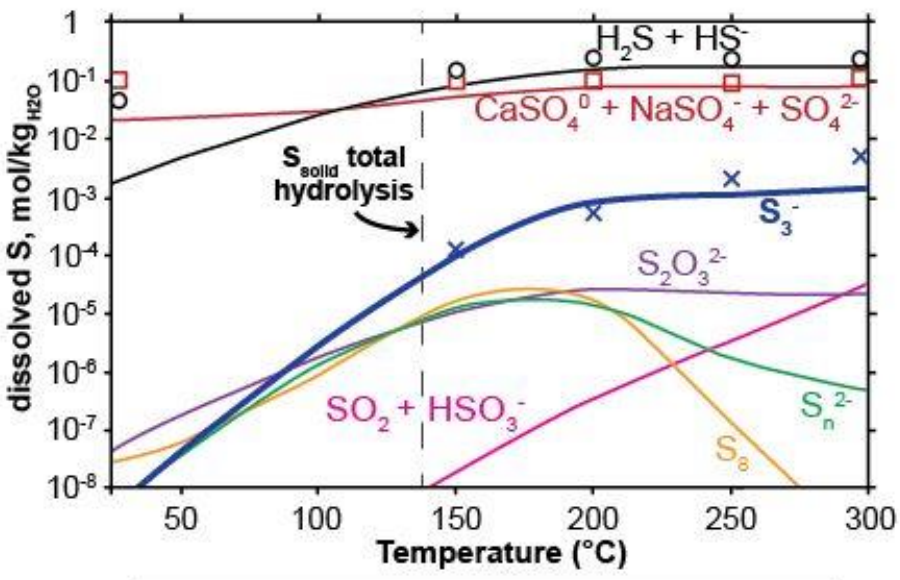

(c) $200^{\circ} \mathrm{C} ; \mathrm{S}_{\text {tot }}=0.25 \mathrm{~m} ; 3.3 \mathrm{~m} \mathrm{NaCl} ; 1.6 \mathrm{~m} \mathrm{CaCl} ; \mathrm{pH}=5$

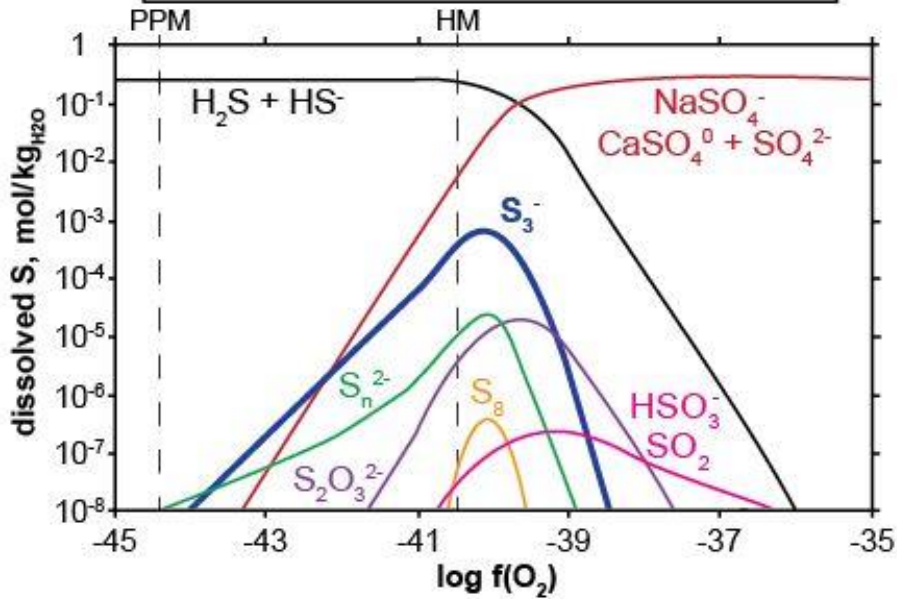

(b) $200^{\circ} \mathrm{C} ; 3.3 \mathrm{~m} \mathrm{NaCl} ; 1.6 \mathrm{~m} \mathrm{CaCl}_{2} ; \mathrm{HM}$ buffer; $\mathrm{pH}=5$

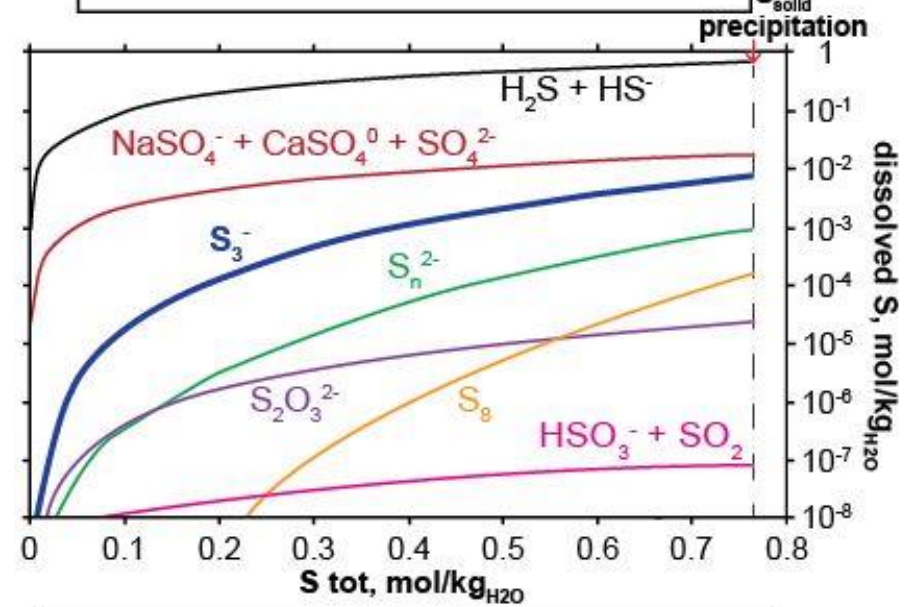

(d) $200^{\circ} \mathrm{C} ; \mathrm{S}_{\text {tot }}=0.25 \mathrm{~m} ; 3.3 \mathrm{~m} \mathrm{NaCl} ; 1.6 \mathrm{~m} \mathrm{CaCl} ; \mathrm{HM}$ buffer

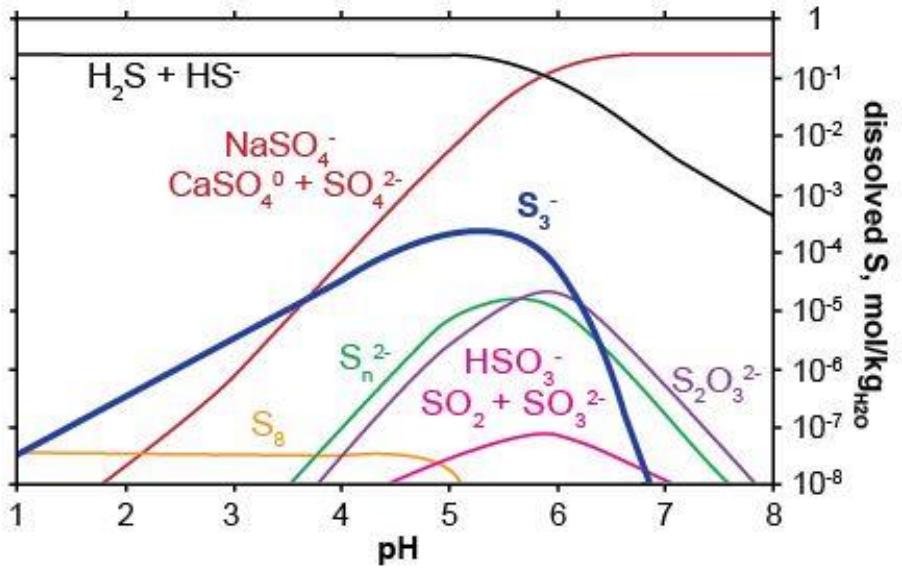




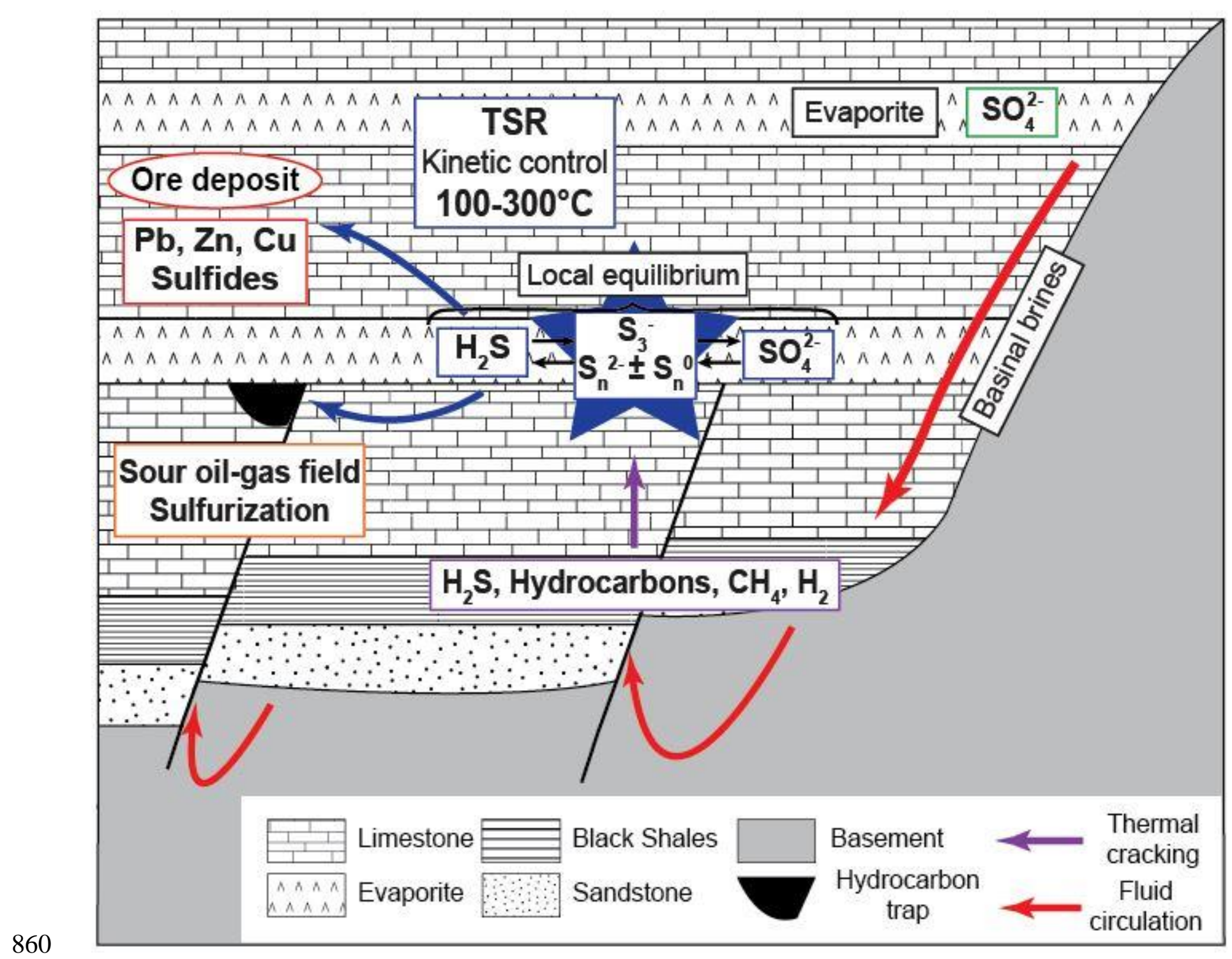


Table 1

\begin{tabular}{|c|c|c|c|c|c|c|c|c|}
\hline $\begin{array}{c}\text { Host } \\
\text { mineral }\end{array}$ & $\begin{array}{c}\text { Fluid } \\
\text { Inclusion }\end{array}$ & $\mathbf{T}\left({ }^{\circ} \mathbf{C}\right)$ & $\begin{array}{c}\mathrm{A} \mathrm{S}_{3}-\text { l } \\
\mathrm{A} \mathrm{H}_{2} \mathrm{O}\end{array}$ & $\begin{array}{c}{\left[\mathrm{S}_{3}^{-}\right]} \\
(\mathrm{mol} / \mathrm{kg} \\
\left.\mathrm{H}_{2} \mathrm{O}\right)\end{array}$ & $\begin{array}{c}\mathrm{A} \mathrm{SO}_{4}{ }^{2-} / \\
\mathrm{A}_{2} \mathrm{O}\end{array}$ & $\begin{array}{c}{\left[\mathrm{SO}_{4}{ }^{2-}\right]} \\
\left(\mathrm{mol}^{2} / \mathrm{kg}\right. \\
\left.\mathrm{H}_{2} \mathrm{O}\right)\end{array}$ & $\begin{array}{l}\mathrm{A} \mathrm{H}_{2} \mathrm{~S} / \\
\mathrm{A}_{2} \mathrm{O}\end{array}$ & $\begin{array}{c}{\left[\mathrm{H}_{2} \mathrm{~S}\right]} \\
(\mathrm{mol} / \mathrm{kg} \\
\left.\mathrm{H}_{2} \mathrm{O}\right)\end{array}$ \\
\hline \multirow{4}{*}{ Quartz } & So. 10 t1 & 25 & - & - & 0.0020 & $1.06 \times 10^{-1}$ & 0.0009 & $4.80 \times 10^{-2}$ \\
\hline & & 200 & 0.0057 & $6.58 \times 10^{-4}$ & 0.0039 & $1.55 \times 10^{-1}$ & 0.0009 & $7.72 \times 10^{-2}$ \\
\hline & & 250 & 0.0097 & $1.05 \times 10^{-3}$ & 0.0039 & $1.51 \times 10^{-1}$ & 0.0013 & $1.14 \times 10^{-1}$ \\
\hline & & 300 & 0.0312 & $2.51 \times 10^{-3}$ & 0.0053 & $1.96 \times 10^{-1}$ & 0.0024 & $1.55 \times 10^{-1}$ \\
\hline \multirow[t]{4}{*}{ Quartz } & So. 10 t3 & 25 & - & - & 0.0015 & $7.64 \times 10^{-2}$ & 0.0007 & $3.53 \times 10^{-2}$ \\
\hline & & 200 & 0.0027 & $3.10 \times 10^{-4}$ & 0.0019 & $7.63 \times 10^{-2}$ & 0.0012 & $1.06 \times 10^{-1}$ \\
\hline & & 250 & 0.0125 & $1.36 \times 10^{-3}$ & 0.0018 & $7.04 \times 10^{-2}$ & 0.0021 & $1.80 \times 10^{-1}$ \\
\hline & & 300 & 0.0199 & $1.61 \times 10^{-3}$ & 0.0008 & $2.87 \times 10^{-2}$ & 0.0021 & $1.32 \times 10^{-1}$ \\
\hline \multirow[t]{4}{*}{ Quartz } & So. 10 t4 & 25 & . & - & 0.0020 & $1.01 \times 10^{-1}$ & 0.0008 & $4.24 \times 10^{-2}$ \\
\hline & & 200 & 0.0028 & $2.91 \times 10^{-4}$ & 0.0031 & $1.11 \times 10^{-1}$ & 0.0015 & $1.25 \times 10^{-1}$ \\
\hline & & 250 & 0.0112 & $1.05 \times 10^{-3}$ & 0.0038 & $1.26 \times 10^{-1}$ & 0.0016 & $1.18 \times 10^{-1}$ \\
\hline & & 300 & 0.0068 & $4.49 \times 10^{-4}$ & 0.0021 & $6.53 \times 10^{-2}$ & 0.0007 & $3.75 \times 10^{-2}$ \\
\hline \multirow[t]{4}{*}{ Quartz } & So. 10 t5 & 25 & - & - & 0.0013 & $6.81 \times 10^{-2}$ & 0.0009 & $4.67 \times 10^{-2}$ \\
\hline & & 200 & - & - & 0.0020 & $8.09 \times 10^{-2}$ & 0.0027 & $2.47 \times 10^{-1}$ \\
\hline & & 250 & 0.0142 & $1.55 \times 10^{-3}$ & 0.0011 & $4.43 \times 10^{-2}$ & 0.0014 & $1.20 \times 10^{-1}$ \\
\hline & & 300 & 0.0068 & $5.47 \times 10^{-4}$ & 0.0008 & $3.01 \times 10^{-2}$ & 0.0021 & $1.37 \times 10^{-1}$ \\
\hline \multirow[t]{4}{*}{ Quartz } & So. 10 t6 & 25 & - & - & 0.0020 & $1.06 \times 10^{-1}$ & 0.0010 & $5.11 \times 10^{-2}$ \\
\hline & & 200 & 0.0030 & $3.46 \times 10^{-4}$ & 0.0019 & $7.79 \times 10^{-2}$ & 0.0012 & $1.06 \times 10^{-1}$ \\
\hline & & 250 & 0.0027 & $2.94 \times 10^{-4}$ & 0.0007 & $2.75 \times 10^{-2}$ & 0.0015 & $1.33 \times 10^{-1}$ \\
\hline & & 300 & 0.0051 & $4.08 \times 10^{-4}$ & 0.0020 & $7.60 \times 10^{-2}$ & 0.0013 & $8.37 \times 10^{-2}$ \\
\hline \multirow[t]{3}{*}{ Quartz } & So. 2.4 t1 & 200 & 0.0069 & $7.12 \times 10^{-4}$ & - & - & 0.0111 & $8.98 \times 10^{-1}$ \\
\hline & & 250 & 0.1047 & $1.09 \times 10^{-2}$ & - & - & 0.0110 & $9.05 \times 10^{-1}$ \\
\hline & & 300 & 0.3842 & $2.91 \times 10^{-2}$ & - & - & 0.0148 & $9.05 \times 10^{-1}$ \\
\hline \multirow[t]{4}{*}{ Fluorite } & So. 10.1 t2 & 25 & - & - & 0.0025 & $1.32 \times 10^{-1}$ & 0.0017 & $8.40 \times 10^{-2}$ \\
\hline & & 200 & - & - & 0.0018 & $7.37 \times 10^{-2}$ & 0.0019 & $1.69 \times 10^{-1}$ \\
\hline & & 250 & 0.0073 & $7.87 \times 10^{-4}$ & 0.0029 & $1.14 \times 10^{-1}$ & 0.0017 & $1.48 \times 10^{-1}$ \\
\hline & & 300 & 0.0391 & $3.32 \times 10^{-3}$ & 0.0056 & $2.58 \times 10^{-1}$ & 0.0050 & $3.10 \times 10^{-1}$ \\
\hline \multirow[t]{3}{*}{ Fluorite } & So. 10.1 t1 & 25 & - & - & 0.0018 & $9.26 \times 10^{-2}$ & 0.0010 & $5.09 \times 10^{-2}$ \\
\hline & & 200 & 0.0043 & $4.97 \times 10^{-4}$ & 0.0024 & $9.74 \times 10^{-2}$ & 0.0014 & $1.31 \times 10^{-1}$ \\
\hline & & 200 & 0.0040 & $4.63 \times 10^{-4}$ & 0.0015 & $6.09 \times 10^{-2}$ & 0.0026 & $2.32 \times 10^{-1}$ \\
\hline \multirow[t]{2}{*}{ Fluorite } & So. 10.1 t3 & 250 & 0.0091 & $9.92 \times 10^{-4}$ & 0.0013 & $4.93 \times 10^{-2}$ & 0.0010 & $8.68 \times 10^{-2}$ \\
\hline & & 300 & 0.0311 & $2.51 \times 10^{-3}$ & 0.0033 & $1.22 \times 10^{-1}$ & 0.0015 & $9.64 \times 10^{-2}$ \\
\hline Fluorite & So. 10.1 t5 & 25 & - & - & 0.0021 & $1.07 \times 10^{-1}$ & 0.0006 & $3.30 \times 10^{-2}$ \\
\hline Fluorite & So. 10.1 t6 & 25 & - & - & 0.0014 & $7.31 \times 10^{-2}$ & 0.0007 & $3.32 \times 10^{-2}$ \\
\hline
\end{tabular}

863

864 